\title{
Assessment of the Effective total quality management on performance at selective colleges in Tigray regional administrative State, Ethiopia,
}

\author{
Gezae Hailu Fissuh ${ }^{\mathrm{a}}$, Yemane Hailu Fissuh ${ }^{\mathrm{b}}$, Zaid Negash ${ }^{\mathrm{c}}$, Haftom Girmay ${ }^{\mathrm{d}}$ \\ ${ }^{a}$ Department of Management, Adigrat University, Adigrat, Tigray, Ethiopia \\ ${ }^{b}$ Department of Statistics, Beijing University of Technology, Beijing, China \\ ${ }^{c}$ Department of Management, Adigrat University, Adigrat, Tigray, Ethiopia \\ ${ }^{d}$ Department of Management, Adigrat University, Adigrat, Tigray, Ethiopia
}

\begin{abstract}
Background: This study attempted to fill a gap in the literature regarding the study of relationships among specific variables, or building blocks, associated with TQM and their use within selective TVET colleges of Tigray state particularly, the eastern zone of Tigray. The study was focused on the TQM and some measuring constructs of TQM. TQM is one of management system like QFD, Six Sigma, ISO 9001, the MBNQA, CQI, Strategic Planning, and the BSC; those are often met with skepticism among leaders of higher educations. Objective: The main aim of this study was assessment of the effective TQM on performance at selective TVET colleges in Tigray, Ethiopia and assessment of associated measuring and affecting factors. Because of time and financial limitations, the study was delimited only on the selective TVET colleges of Eastern zone of Tigray.

Methods: Both qualitative and quantitative analysis was conducted passing many procedures through different sources of data. Stratified sampling was employed. Out of Total 7189, sample of 365 was selected. Binary logistic and multiple linear regressions were modeled to measure the relationship among different constructs of $T Q M$.

Results and findings: $54.9 \%$ of variability in product/service quality and $61.4 \%$ of variability in satisfaction were explained by the independent variables altogether and overall multiple regression models were statistically significant ( $p$-value<0.001). Besides of multiple linear regressions, the Hosmer-Lemeshow goodness-of-fit test for both binary logistic regression models with HL statistic $\left(X_{8}^{2}=12.001(P-\right.$ value $=$ $0.151))$ and $\left(X_{8}^{2}=3.861(P-\right.$ value $\left.=0.869)\right)$, indicated that the models are good fit to the data by rejecting $H_{0}$ : the model is not fit.

Conclusions: Finally, multiple linear regression models for both response variables which are the constructs of TQM showed that there are enough association among the dependent constructs of TQM and independent constructs of TQM. So, the strength of the relationship between dependent variables product/service quality and satisfaction with independent variables suggests that TQM practitioners should place more importance on leadership, continuous improvement, internal/external cooperation, employee fulfillment and customer focuses. Keywords: Total quality management, Performance, Product/service Quality, Satisfaction, Binary logistics regression, multiple linear regressions
\end{abstract}

\section{Introduction}

The most widely used quality improvement methodologies from industry are examined in the context of higher education: Quality Function Deployment (QFD), Six Sigma, ISO 9001, the Malcolm Baldrige National Quality Award, and Continuous Quality Improvement (CQI) measures such as Total Quality Management (TQM), Strategic Planning, and the Balanced Scorecard are often met with skepticism among leaders of higher education. TQM was found to have the largest number of historical applications in higher education, while QFD is gaining in popularity. Other techniques observed in industry have seen only limited use in higher education in the United States. The Academic Quality Improvement Program (AQIP), a continuous improvement technique used exclusively in higher education, highlights how higher education has adapted quality management techniques in the framework of collegiate accreditation. AQIP offers institutions of higher education a new, 'continuous improvement' method of maintaining accreditation.

Administrative traditional Patterns are no longer useful methods for higher education institutions, since the current stage of life in the world are rapidly evolving and changing, which makes the task of the Universities and Colleges in the society more difficult than before. Universities and Colleges should pursue this new development but must be preceded to the right direction for the benefit of humanity (Suleiman, 1979). To meet economic, social and cultural challenges require flexible organizational structures and an implementing trend of modern management approach characterized by flexibility, portability and the ability to take advantage of 
modern culture. In order to meet these responsibilities, there are many challenges facing an institution, including diverse demands for scarcity of material and human resources. Failure to adopt modern management techniques by the colleges, which proved achieving the desired results, such as total quality management (TQM) philosophy, is a case that worth making research, study and analysis to arrive at a mechanism of action enable these institutions to adopt this modern management approach.

Generally, like many Continuous Quality Improvement (CQI) theories, Total Quality Management (TQM) offers its users a method to understand what is happening within an organization and ways to improve quality and efficiency.

\subsection{Background of Study}

The significance of education in the development of a country cannot be underestimated (Ali et al., 2010). It is education that develops expertise, excellence and knowledge that lead to the overall enlargement of any economy. This has created a necessity to develop the strategies for the development of Higher Education (HE) in almost all the countries of the world (Ali et al., 2010). Thus the success of higher education institutions (HEIs) depends on how the educational leaders work to implement the strategies (Ali et al., 2010). Thus, this study is concerned with the private and governmental selective TVET colleges to check the TQM of the corresponding colleges and also to compare the TQM in different colleges of private and governmental with associated factors.

Total quality management (TQM) can be summarized as a management system for a customer/studentfocused organization that involves all employees in continual improvement. It uses strategy, data or information, and effective communications to integrate the quality discipline into the culture and activities of the organization.

The theory of 'Total Quality Management' (TQM) is well adopted by educational leaders in HE sector to achieve the aim of quality education. Universities and colleges i.e., HEIs in Ethiopia are also adopting quality measures to improve the quality of education. Ethiopia is still young and striving to become medium largest HE sector in the world. However, only few HEIs like private and/or governmental colleges and Universities are striving to provide world class education therefore, Tigray is also one of the regional states of Ethiopia trying to fulfill the requirements of Millennium goals in higher educations (HE) (Ali et al., 2010).

Hence, this paper will discuss the importance of quality in colleges' management and the reasons why TQM as a theory of quality management by leadership efforts should be used in colleges for a sustainable improvement on performance. It also will discuss how the leadership quality of management or the head of colleges facilitate the implementation of TQM as a tool for holistic development of HEIs (Ali et al., 2010).

'Total Quality Management' (TQM) in HEIs has been an important agenda in many countries for the last several years. Quality management is a necessary strategy for the development of the HEIs because higher education develops the human resources and professionals for future. According to Ali and Shastri (2010), World Bank recently revealed, after a study in 190 countries, that it is HE that produces quality professionals. Therefore, HE is an investment to improve the quality of life. There is a clear link between the education and economy.

Pandiet al. (2009) stated that, developed countries like USA, UK and Japan have already recognized the importance of TQM in HE and adopted it successfully in their HE system. However, the management in HEIs in developing countries like Ethiopia has not demonstrated the leadership potential which is required to manage total quality in HEIs.

As HE has a variety of stakeholders like students, teaching and non-teaching staffs, employers, government and its funding agencies, accreditors and auditors (Harvey and Burrows, 1992) the concept of quality becomes very complex. Every stakeholder defines the term quality according to his or her own interest. For example, to a student, quality in HE means its ability to provide him with proper facilities to continue the process of advancement of knowledge. For government, it is the production of engineers, doctors, architects and trained scientists (Singh et al., 2008). Similarly, for an industrialist quality in HE means turning out graduates with flexible mind ready to acquire skills and adapt to new methods (Singh et al., 2008). Therefore, it becomes important to understand what do the intellectuals understand by TQM and how do they define it. This will help to understand the implementation of TQM in HE at government agencies level as well as universities or HEIs level. Understanding of TQM also reveals the role of educational leaders in its implementation and opens the way for its successful implementation.

\subsection{Statement of the Problem and Research Questions}

A large body of literature exists on the success or failure of TQM within the corporate world, and regardless of how an individual views TQM; it is difficult to deny that TQM has made a significant impact on the business world over the past 50 years. While much is written about TQM in the corporate world, far fewer articles are devoted to the success or failure of TQM within higher education even though many colleges and 
universities attempted to implement TQM or some other form of CQI within their institutions (Burkhalter, 1996).

Even though Ethiopian government is striving to improve the expansion of the higher educational institutions like colleges and universities still there is limited works done on the quality. That may be because of the lack of quality in management to achieve the standard TQM system.

As it is fact, the environment in which the Ethiopian colleges operate is rapidly changing. There is a rapid enrolment expansion in colleges. The private and governmental colleges are also facing inconsistent policy direction. Under such circumstances, the both private and governmental colleges are required to establish and implement internal quality assurance mechanisms to safeguard and improve the standards and quality of their education programs (Proclamation 650/2009). Therefore, in order to bring good quality in their service and customer satisfaction the colleges must have effective TQM in their institutions. The issue of whether both private and governmental colleges are actually implementing quality assurance mechanisms to improve quality of their education and implementing the effective TQM, the current changing environmental context is not clear.

This fundamental research problem is further broken down into basic research questions. As this study comprises analyses of organizational level TQM systems and practices, it deals with terms and concepts like quality in service, satisfaction of the customers, continuous quality improvement and performance management models and their underlying assumptions and with theories that can be used to explain how contextual factors influence existing practices. Hence, the first research question of this study can be put as:

1. What is Total Quality Management and why should it be implemented in colleges?

2. What are the implications for TQM in selective TVET colleges in Tigray in relation to providing high quality educational provision?

3. What is the empirical evidence of TQM being used in different context and how effective they are?

4. Are there differences among the colleges regarding TQMpractices? What are the possible explanations for such differences?

5. What are the indicator factors for efficacy of TQM in performances in selective colleges?

\subsection{Objective of the Study}

\subsubsection{General objective}

The general aim of this study is assessment of the effective total quality management on performance at selective colleges in Tigray regional administration and assessment of associated factors.

\subsection{2. $\quad$ Specific objective}

$\checkmark \quad$ To identify components, associated with the use of TQM within selective colleges.

$\checkmark \quad$ To verify the existence of TQM on performance of selective colleges in Tigray

$\checkmark \quad$ To compare the effective implementation of TQM on performance at selective colleges.

$\checkmark \quad$ To check the quality of the management on performance at selective colleges

\subsection{Scope of the Study}

This study is focused about the general aim of the assessment of the effective total quality management on performance at selective colleges in Tigray regional administration and assessment of associated factors. The study is delimited on the target populations of selective colleges in Tigray regional administration. Because of time and financial constraints, the study will be delimited only on the selective colleges of Eastern zone of Tigray regional administrative state.

\subsection{Significance of Study}

After the successful completion, the importance of this study will be as follows:

This research will illustrate the concept of (TQM) as a modern approach that leads to upgrade quality performance of the Colleges as well as for compensation for the shortfall of literature and research in this topic.

This study is significant as it attempts to fill a gap in the literature regarding the study of relationships among specific variables, or building blocks, associated with TQM and their use within selective colleges of Tigray. Since current research exploring the effectiveness of TQM in selective colleges of Tigray is rather sparse, it is important to undertake a quantitative study that attempts to explore these relationships. This study can serve as a bridge between existing researches measures where TQM is used within higher educational institutions such as colleges and Universities.

This study can also be generalized beyond the academic world into public and private business, as it is a study of how leaders evaluate TQM concepts within their organizations. Thus, if an organization identified a need to improve their employee or customer satisfaction, the results from this study could be used to identify what specific components of TQM have positive relationships with the desired outcome. This would prevent a 
TQM practitioner from potentially selecting the wrong components to implement and thus leading to failure in the area they wish to improve.

\subsection{Definitions of the Terms}

Total Quality management (TQM): -According to the definitions ofHo and Wearn (1995, p. 25) TQM is defined as 'a way of managing to improve the effectiveness, efficiency, cohesiveness, flexibility, and competitiveness of a business as a whole.' They further offered a list of principles required for successful TQM implementation, including leadership, commitment, total customer satisfaction, continuous improvement, total involvement, and education, ownership of problems, reward and recognition, error prevention and teamwork.

training

Customer-focused: - The customer ultimately determines the level of quality. No matter what an organization does to foster quality improvement-training employees, integrating quality into the design process, upgrading computers or software, or buying new measuring tools the customer determines whether the efforts were worthwhile.

Total employee involvement: - all employees participate in working toward common goals. Total employee commitment can only be obtained after fear has been driven from the workplace, when empowerment has occurred, and management has provided the proper environment. High-performance work systems integrate continuous improvement efforts with normal business operations. Self-managed work teams are one form empowerment.

Process-centered: - A fundamental part of TQM is a focus on process thinking. A process is a series of steps that take inputs from suppliers (internal or external). The steps required to carry out the process are defined, and performance measures are continuously monitored in order to detect unexpected variations.

Integrated system: - Although an organization may consist of many different functional specialties often organized into vertically structured departments, it is the horizontal processes interconnecting these functions that are the focus of TQM.

Micro-processes add up to larger processes, and processes aggregate into the business processes required for defining and implementing strategy. Everyone must understand the vision, mission, and guiding principles as well as the quality policies, objectives, and critical processes of the organization. Business performance must be monitored and communicated continuously.

An integrated business system may be modeled after Baldrige National Quality Program criteria and/or incorporate the ISO 9000 standards. Every organization has a unique work culture, and it is virtually impossible to achieve excellence in its products and services unless a good quality culture has been fostered. Thus, an integrated system connects business improvement elements in an attempt to continually improve and exceed the expectations of customers, employees, and other stakeholders.

Strategic and systematic approach: - A critical part of the management quality is the strategic and systematic approach to achieving an organization's vision, mission, and goals. The process, called strategic planning or strategic management, includes the formulation of a strategic plan that integrates quality as a core component.

Continual improvement: - A major thrust of TQM is continual process improvement. Continual improvement drives and organization to be both analytical and creative in funding ways to become more competitive and more effective at meeting stakeholder expectations.

Fact-based decision making: - in order to know how well an organization is performing, data on performance measures are necessary TQM requires that an organization continually collect and analyze data in order to improve decision making accuracy, achieve consensus, and allow prediction based on past history.

Communications: - During times of organizational change, as well as part of day-to-day operation, effective communications play a large part in maintaining morale and in motivating employees at all levels. Communications involve strategies, method, and timelines.

Finally, these elements mentioned above are considered so essential to TQM that many organizations define them, in some format, as a set of core values and principles on which the organization is to operate. Source: http://asq.org/learn-about-quality/total-quality-management/overview/overview.html 


\subsection{Assumptions in this study}

Several assumptions will be made for this research, the first of which will be that the investigator would receive a greater response rate through the use of a questionnaire survey, interviews, group discussions and by reviewing the recorded files and documents than a web-based survey. This assumption was based upon the situations and regular conditions of Ethiopian websites. Since, Ethiopian websites are not enough good to have relevant information or data. This assumption contradicts the assumption based upon the research conducted in 1998 by Nesbary (2000) because his assumption was web based survey is more relevant than traditional postal delivered survey.

A second assumption will be the recipients of the survey will in a position that allowed them to evaluate TQM within their organization. All of the respondents will assumed to be college presidents or management bodies, employees and customers/ students, so it is assumed they will be in a position to evaluate the use of TQM within their college (Nesbary, 2000).

A third assumption will be the variables and performance measures the survey asked selective TVET college presidents or management bodies, employees and customers or students to give their perceptions of will be accurate components of TQM. The surveyor believes this will be a valid assumption as these variables and measures are based upon extensive evaluation by Anderson et al (1994) and also Grandzol and Gershon (1997, 1998). Using the Delphi technique to solicit responses from experts in the field of TQM, this previous research established valid variables and measures of the components of TQM.

\subsection{Organization of the paper}

This master thesis is organized in six main chapters. Each chapter of the study addressed a specific theme. The first chapter dealt with the background of the study, statement of the problem, research questions, delimitations and scope of the study, hypothesis of the study, significance of the study, and definition of key terms. The second chapter clearly described literature review. The third chapter dealt with methodology of the study such as: proposed research design, study population, study area, data source and data collection, sample size determination and sampling techniques, method of information gathering, study variables and proposed data analysis are comprised under this chapter. The fourth chapter dealt with results and findings. The fifth Chapter dealt with discussions and last chapter dealt with conclusions and recommendations.

\subsection{Introduction}

\section{Literature Review}

Management systems such as TQM, Six Sigma, and Strategic Planning are popular methods that organizations use to improve performance. While these techniques are popular in business and manufacturing firms, higher education has not extensively adopted these systems into their daily activities (Taylor \& Karr, 1999). What makes acceptance and integration of these systems difficult is the viewpoint held by many campus leaders that they would rather shape the future of their campus based on their individual experiences and the experiences of those close to them (Petrides, 2003). As a result, leaders can become hesitant to embrace a system regarded as rigid, fearing that their individual creativity can be blocked.

\subsection{Definitions}

Quality management in education is a vital milestone in the development of the modern and future society. The cohesion of the requirements of students, society and university staff is the foundation of sustainable knowledge spiral to quality education. In order to examine the problem thoroughly one should study the motivation of the parties involved in the process (Gueorguiev, 2006).

\subsection{Total Quality Management \\ What is 'Total Quality Management?}

Total quality management (TQM) was first introduced as a business management approach in the postWorld War II era when Deming and others successfully reinvented the Japanese economy. Beginning in the early 1980s, American business leaders looked to the philosophy, principles, and TQM tools to improve the economy. More recently, education leaders have begun to recognize the potential for TQM applied to educational organizations. Quality management provides a connection between outcomes and the process by which outcomes are achieved. If, as many people realize, the cause of failures in education is a problem in design, quality management may be regarded as an ideal systemic process for managing change in public education (Frazier, 1997).

The concept of quality management first appeared in 1951 (Zink and Vob, 2000). Generally, the term 'Quality' is associated with consumer satisfaction. Customers want the best return for the money they pay to buy something. According to Sims and Sims (1995), "Customers would examine products to see if they met their standards prior to purchasing them". Therefore, industries and organizations try to ensure that the products 
launched or marketed by them should be well prepared to satisfy the consumers' need. TQM aims to manage the quality of product and services provided by the organizations to make customers satisfied. Sims and Sims (1995, p 1), define TQM as- TQM is the process of continuous improvement using selected tools, techniques, and training to guide decision making and to plan actions. The results are quality processes, products, and services, and thus high level of customer satisfaction. Thus, TQM is a holistic approach that furnishes cognizance of the relationship between customer and supplier by the continuous efforts of improvement in all the departments and functions of an organization (Smith et al., 1999, p.55).

TQM is not just confined to production or services. It also influences the other components like work culture, employees, employees' attitude and other departments of an organization. Voehl (1994, p. 28), claims that total quality covers three senses, first 'every process' second 'every job' and third 'every person'. It points out that to ensure total quality each and every department of an organization must be responsible for the quality of their work. Similarly, Oakland (2003, p. 15) argues that each of the components of an organization must work properly in order to maintain quality as each part, each activity, each person related to organization affects others and get affected by them.

\subsection{Total Quality Management in Higher Education}

"TQM was initially used for the measurement of quality in the HE sector in 1993" (Clayton, 1993). Infect the concept of TQM has come to HE from the business communities. Ideally education should not be related to business as it is to develop values and the personality of a student. HE too is to make students a learned person and a qualified professional and eventually a good citizen. But there is a clear component of business as HEIs charge fees from the students and hence students become selective in choosing the universities and the course they want to study. Keeping these points in mind the significance of TQM in HE can be discussed in two sub-headings (i) HE as a business and (ii) HE as service for human development.

\section{i. HE as a business}

Some authors believe that colleges and universities should be considered as a business because they have to compete with other colleges and universities and their funding resources are limited hence they need to generate money. Arjomandi (2009) claims that in twenty first century colleges and universities have to adopt business-like strategies to cope with the increasing market competition and limited funding opportunities. That is why implementation of quality management has become important in HE for instance, colleges. Moreover, Warner and Palfreyman (2000) reported that HEIs are like enterprises as they collect the fees (money) in cash which is the life blood of any enterprise. Tuition fees for students give them a chance to do business as it is a matter of individual institution.

The colleges, therefore, need to maintain quality as they have to attract students to fulfill their funding needs. As the students pay fees they examine not only the quality of education provided by some colleges but also other services like student support services, student leaning resources, student communication and representation and student assessment. In fact, they act as consumers. So it becomes important for the colleges to assure quality by accreditation and outcome assessment. TQM might support better inputs by focusing on students' achievement, good faculty members and other facilities like library and laboratory to get better output as high quality outputs results if high quality inputs exist (Voehl, 1994, pp. 10-11).

\section{ii. HE as a service for human development}

$\mathrm{HE}$, in general, is considered to encourage personal growth and social responsibilities in an individual, in addition to his professional training and academic development. It also educates students to become civic responsible and a citizen of global society (CEPES, 2009). HE must lead to ethical development of students while its process of imparting education. The standard of education has its direct impact on the development of the students' understandings.

Gupta (1993) recognizes 'teaching' (transfer of knowledge) as one of the most important activities which take place in any educational institute. According to him improvement in the quality of teaching is one of the most important aims of any professor in HEIs. As teaching is a process of transforming knowledge it must have quality in it because without quality the process of teaching could not achieve the desired level of education. Though TQM is accepted as a concept in business organizations still it could be used as a tool to achieve the goal of improving quality in teaching. Voehl's theory (1994, pp. 10-11) of high quality input for high quality output is significant in this case too. If teachers are committed to develop values in students along with their professional training TQM might support to hire teacher with dedication to develop their students as good citizens.

In addition to teaching HE is also considered to be the training for the research works. Barnett (1992), states that the members of academic community believes that to assure quality in education the research profiles of the staff is more important to the achievement of the students as students achieve success if they are in a 
small group, in the company of recognized researchers. A small group of students discourage business but encourage teaching and learning process.

The above discussion reveals that the quality management in HE is important in either case. HEIs need quality management to enhance the quality of education for better service to mankind as well as to fulfill the expectations of its students in order to keep their position secure.

Generally, through an extensive literature review, they identified specific operational practices that could be measured to determine how they influence concepts associated with TQM. These variables are identified as operational concepts or constructs by the researchers. Having identified these constructs, Grandzol and Gershon (1997) developed a survey instrument to test the theory that there exists "causal relationships between the constructs and the measures". The constructs are listed in bold with the performance measures following:

- Leadership: Clarity of vision, long-range orientation, coaching management style, participative change, employee empowerment, planning/implementing change.

- Continuous Improvement: Refinement cycles, improvements.

- Internal/External Cooperation: Firm-supplier partnership, single-supplier orientation, collaborative organization, teamwork, organization-wide involvement, systems view, trust, elimination of fear.

- Customer Focus: Customer driven focus.

- Learning: Company-wide training, foundational knowledge, process knowledge, educational development, continuous self-improvement, managerial learning.

- Employee Fulfillment: Job satisfaction, job commitment, pride of workmanship.

- Process Management: Prevention orientation, reduction of mass inspection, design quality, statistical process control, understanding variation, elimination of numerical quotas, elimination of merit ratings, understanding motivation, total cost accounting, stable employment.

- Product/Service Quality: Accuracy, completeness, conformance, innovation.

- Operational Efficiency: Productivity, cycle time, scrap/waste, energy/efficiency, material usage.

- Financial Effectiveness: Return on investment, market share, capital investment ratio.

- Public Responsibility: Environmental complaints, community involvement.

- Employee Satisfaction: Turnover, requests for transfer, grievances/complaints, absenteeism, surveys.

- Customer Satisfaction: Surveys, complaints, inquiries.

\subsection{Concept of Quality}

The concept of Quality Management is considered as one of modern management approach based on a set of ideas and principles that can be applied to any institution to achieve the best possible performance, improve productivity, increase profits and improve the Organization's reputation in domestic and external markets. The concept of quality has been changed following the development of management science with new dimensions (Daradkeh and Shibli, 2002). Management researchers and scholars have argued on the definition of (TQM) based on their cultural back ground and philosophy. Therefore, it is a management philosophy, strategic approach and mean of change aimed to transfer modern organizations to patterns of thought and action fits with environment and modern future requirements (Dagher, 2001).

\subsection{The Adoption of (TQM) In Higher Education Institutions}

The adoption of TQM in higher education has many reasons and motives as follows: -

- Costs: A low level of spending in higher education makes Colleges seeks control of cost. TQM is a mean of tools and principles to control costs during service (Decosmo, 1991). Expenditure on education is increased, and must be linked to benefit return which is to undertake the role of actual developmental contribute to the advancement of civilization through the quality of performance (Ibrahim, 2001).

- Competition: Colleges and Universities should keep up with student's loyalty (Sims and Sims, 1995). Also they have a strong competition as each institution seeks to attract the largest possible number of students through compliance with international standards. The College's overall survival is accomplished by meeting the best needs for students and society. The adoption of (TQM) enhances credibility to meet the requirements of the College's performance which leads to improve its competitive position among other similar academic institutions (Cornesky, 1994).

- Quality of higher education and reliability Now a days Governments are keen to assess the quality of higher education more than ever and trying to apply quality and reliability more widely to develop the society and realizing that (TQM) is achieving high level of quality for the development of the higher education institutions.

- Service directives after it was the concerned of planners and beneficiaries, Public participation in restructuring public institutions provides better service by adopting quality standards. the standard of 
educational quality, regardless of its nature, is the criterion capable of showing the value of quality that characterize educational service provided for students, namely: acts of education (teaching and learning processes and evaluation), education environment (policies, laws, relations, models and expectations) and educational content such as knowledge, skills, values (Wahbe, 2003). Colleges have to work on students' preparations for the real world, which affirm continuous change of the work (Sims and Sims, 1995).

\subsection{The Contents of (TQM) in Higher Education}

The most important application of TQM in higher education is the beneficiary satisfaction, desires and aspirations, as in this case, students are the beneficiaries (Morgan and Murgatroyd, 1997). Therefore, the satisfaction is the crucial factor in the success of the higher education institutions and student satisfaction and development must be the focal point in all practices of (TQM) (Sims and Sims, 1995). Students' contribution was excluded in the past for planning educational process, however, contemporary trends such as (TQM), which confirms that significant gains through the involvement of undergraduate students in institutional planning enable them to explore new ideas. Scientific experiments have proved that involvement of students would achieve added benefits for faculty members and students, as well as the involvement of faculty and administrative staff in the development of the College. According to Saeed (2001), 37-2001 Universities and Colleges focused on the following aspects: Full absorption of the beneficiaries, s needs and requirements using feedback for the sake of the continuity's development. By Connecting the students for needs with educational process design at the higher education institutions the following experiences can be adopted.

- Cooperation and interaction between students and faculty members through an exchange of experiences, advice, and assistance system

- Measure the satisfaction of students and faculty members on the College service through the adoption of comparison criteria between the concerned College's output and other similar Colleges (Abu Nabaa and Massad, 2000). The integration of employees of the College and University plays an important role in bringing management and faculty members close together to solve problems of team work leads to smooth flow of information and encourage individuals to express their views.

According to Al-Khafaji and Babairman (1995) the criteria in order to improve performance of Colleges and quality outputs, the following (TQM) steps should be adopted:

- Identify main beneficiary of the Colleges output.

- Develop the academic institution's mission to enable it for competition through quality performance of education program, students' scientific experiments, service offered to beneficiaries, distinguished academics, services provided to the surrounding environment.

- Set up internal procedures to achieve quality performance.

- Identify individuals and groups who carry out the responsibility of the selected criteria.

- Provide incentives for those who achieve quality.

- Forming teams responsible for quality programs.

- Writing down and recognize achievements of high quality and provide incentives according to the selected criteria.

\subsection{Measurement of (TQM) in Higher Education}

In order to support and encourage continuous improvement process, Universities or Colleges need a set of techniques and tools to reach positive results in improving performance. The most important tools are: -

i. Self-Assessment: - It's one of effective tools that guide the leadership to a manner of how to invest College's resources efficiently to improve its performance compared with an international criterion or with the College itself through the assessment of the implementation of an annual plan with previous year.

ii. Benchmarking: - It is a process to determine where inputs, processes, outputs, systems, and functions are significantly different from those of competitors or others. It's also an ongoing regular process to compare work results at a College or a University with same work at another College or University in the same educational field, taking into consideration concentration on activities, functions, and internal operations (Walton, 1985; Alkazzaz, 2001). This method is the most appropriate technique for higher education. Supporters of this process believe that Benchmarking lead to:

- Determine initial values, goals and monitor improvement through providing objective measurements.

- Make the College's work in such atmosphere to alleviate resistance of change.

- Create a structure of external evaluation.

- Effectiveness of the communication networks of new work and its role in sharing experiences between institutions of higher education and unified strategy (Sanyal, 1998).

- ISO 
Following the Adoption of (TQM) by Colleges and Universities, it is necessary to rely on standards set by the "international standardization Organization (ISO) to ensure quality performance (Ani, 2002). ISO standard is one of a set of management tools that Colleges and Universities have adopted in recent years. Many Colleges and Universities worldwide received ISO certification of their quality management systems. In the United Kingdom more than 20 Colleges received ISO (9002) certification (Ani, 2002).

\subsection{Empirical evidence of TQM being used in different context and its effect}

TQM is being practiced in HE all around the world. Ethiopian HE also has a well-defined system for quality management. There are several evidences of TQM being practiced in HEIs in Ethiopia. However, the majority of them are

Ethiopia possesses a 1,700-year tradition of elite education linked to the Orthodox Church. But secular higher education was initiated only in 1950 with the founding of the UC of Addis Ababa. During the following two decades half a dozen specialized technical colleges were established. These institutions hosted an educational culture that was heavily influenced by its long informal association with the Orthodox Church (Saint, 2004) Ethiopia now boasts about 60 private colleges, which enroll about a quarter of all students. Most of these institutions are based in the capital, Addis Ababa, with a few branch campuses in major towns. Virtually all of these institutions were established in the last half decade. While a closer analysis is warranted, the enrollment rate appears to have been climbing rapidly for several years; but the pace has now moderated, and in a few cases a decline has been reported. (Damtew, 2005) Most private institutions in Ethiopia, like others in Africa, offer courses that render good employment opportunities. The programs include business administration, computer studies, and information technology (IT). Others also provide training in health care and teacher education. A few of these colleges also offer distance education to tens of thousands of students (Damtew, 2005). The study focusing on SMUC, SMUC is an outgrowth of St. Mary's Language School which was established in 1991 in Addis Ababa. St. Mary's College was established in 1998 under St. Mary's General Educational Development PLC with its head office in Awassa and a branch in Addis Ababa. After a lot of hard work and dedication, the College was raised to the level of UC in February 2006. Currently SMUC have managed to graduate more than twenty thousand students in the conventional and distance modes. SMUC offers undergraduate and joint graduate programmes in many fields of studies. Excluding the Distance Education Division, the UC offers courses in ten departments organized under four faculties comprising the Faculties of Business, Law, Informatics and Education. These courses are run under two categories of programs i.e. the Regular Program (run during the day time) and the Extension Program (offered in the evening). Students are trained in the specified levels: the certificate $(10+1$ and $10+2)$, the diploma $(10+3)$ and the degree programs.

Klocinski (1999) has determined the extent of failure and success in implementing (TQM) in educational institutions. A tool applied to 184 educational institutions during the year (1991) and (1996) to find out the extent of implementing quality management. The researcher used a questionnaire with open questions distributed to Colleges and Universities owned by the private and public sector. He found that the number of Colleges and Universities that apply Total Quality Management has been increased). The researcher also found that $74 \%$ of these Colleges in 1991 have had an ongoing (TQM). 86\% are encouraged to follow the overall principles of quality in their administrative operations and services.57\% confirmed that it faces obstacles and problems in implementing (TQM). 37\% said they suffer from a lack of administrative support and a weakness in leadership which is considered a major constraint in implementing (TQM).

Ayoub (2000) seeks to identify the effectiveness of total quality management in the performance of Universities in Jordan. A random sample of (282) faculty members in the Jordanian Governmental Universities have been selected. The researcher was able to develop a questionnaire of (35) points and the paper reached the following conclusions:

- There are statistically significant differences among faculty members in estimating efficiency use of (TQM) to develop performance of the Jordanian Universities, according to the University.

- There are no statistically significant differences among faculty members in estimating efficiency use of (TQM) to develop the performance of the Jordanian Universities, according to the faculty members with different titles.

Dagher (2001) highlights the most important challenges facing higher education in the Arab world and the possibility of meeting those challenges by adopting the philosophy of (TQM). The researcher concluded that the possibility of successful implementation of(TQM) in Universities and Colleges in Iraq and the Arab world, after this approach has proved successful in improving standards, the traditional administrative methods do not match the information revolution experienced by the world in all aspects of life.

Al-saud (2002) clarifies the concept of (TQM) and its steps applied at schools in Jordan. The researcher adopted " Analytic synthetic approach" as a way to identify the nature of (TQM). The characteristics of the research reached that new strategy for the development of educational systems that must be based on 
development inputs of the educational system and should be based on modern approaches, and should implement (TQM) in the educational institutions.

Al-gmeez (2004) has examined the implementation of (TQM) at the Ministry of Higher Education in Saudi Arabia from the perspective of its employees. He found that there are statistically significant differences to the variable years of experience in planning and the potential ability reflects the quality requirements of (TQM) (buildings, playgrounds, laboratories, libraries, classrooms, and educational technology)

\subsection{Scale reliability and validity of constructs}

The Cronbach's alpha reliability test was performed on all TQM constructs by Hoang D.T. et al., (2010), to assess the reliability of the collected data. According to their study, Cronbach's alpha measures the degree to which a construct is internally consistent and reliable. Generally, variables that had items with a total correlation below 0.3 were dropped, while a reliability coefficient of 0.7 or more was considered good (Nunnally\&Burnstein, 1994; Hair et al., 1998). The Cronbach's alpha for all TQM constructs found in their sample were well above 0.7, and all the item-total correlation coefficients exceeded 0.3. Therefore, the instrument developed for measuring TQM and organizational performance constructs was judged to be sufficiently reliable.

In order to examine the TQM construct validity, Hoang D.T. et al., (2010) used the confirmatory factor analysis (CFA) method using AMOS 4.0 with a maximum likelihood procedure. In their study the summary statistics of the analysis variables showed that the variables exhibited a relatively normal distribution with the values of skewness and kurtosis not exceeding very much the absolute value of 1 (Anderson \& Gerbing, 1988; Hair et al., 1998). First, Hoang D.T. et al., (2010) applied a CFA model for each construct to eliminate items with weak loading coefficients (smaller than the cut-off point of 0.5 ) and to validate the measurement model. During their study and validation process, Hoang D.T. et al., (2010) deleted some variables having poor loading on their respective latent variables and those deleted variables were five items (the first item of Teamwork measures; the first, second, and third items of Process Management measures; and the first item of the Information and Analysis measures). After excluding these items, the Goodness of Fit Indexes (GFI) for all constructs well exceeded 0.9 and the Standardized Root Mean Squared Residual (SRMR) coefficients were less than 0.1. These criteria met the requirement for an acceptable model (Kline, 1998). Comparative fit index (CFI), and standardized Root Mean Squared Residual (SRMR) of the final TQM constructs that safeguard the reliability and validity of the constructs under investigation.

Next, Hoang D.T. et al., (2010) used a CFA model to assess the means of the 11 TQM constructs. According to Kline (1998), besides the Chi-square to degrees of freedom ratio ( $\mathrm{x}^{2} / \mathrm{df}$ ratio), the widely used measures of fit for the model include the goodness of fit index (GFI), the Bentler comparative fit index (CFI), the Bentler-Bonett non-normed fit index (NNFI), and the standardized root mean squared residual (SRMR). It is desired that the $\mathrm{x}^{2} / \mathrm{df}$ ratio is less than 3; the GFI, the CFI, and the NNFI are at least 0.90; and the SRMR is less than 0.1. All variables had high factor loading coefficients and highly statistical significance (all p-values equal 0). Thus, all variables that measure latent constructs achieved convergent validity (Anderson \& Gerbing, 1988). This indicates the validation of the measurement model, and also demonstrates that TQM is generally considered as a set of practices, as proven in previous studies (Ahire et al., 1996; Samson \& Terziovski, 1999; Prajogo \& Sohal, 2003). In summary, these results provided the safeguard for the reliability and validity of the TQM constructs under investigation.

Customer satisfaction was also a statistically significant positive predictor within this model, $\beta=0.28$, $\mathrm{p}<.01$. This indicates that employee satisfaction significantly increased with increasing levels of customer satisfaction and was likely not due to chance. A t value of 3.44 indicated a statistically significant measure of the relationship between employee satisfaction and customer satisfaction. B measured the slope of the line and indicated for every one-unit change in employee satisfaction, customer satisfaction increased by 0.20 . The remaining predictors were not significant.

In recently, Riccardi, et al. (2009) in their paper performed multiple linear regressions after the reduction of huge variables in to simple form by using factor analysis in order to build the constructs for TQM. Their interest was to check whether there are statistically significant relationships among independent variables/predictors and responses such as employee satisfaction: leadership, continuous improvement, employee fulfillment, learning, process management, internal/external cooperation, customer focus, product/service quality, operational efficiency, financial effectiveness, public responsibility and customer satisfaction.

Out of several multiple linear regression models they performed, Riccardi, et al. (2009) particularly performed the model with response variable customer satisfaction and the model was a statistically significant with $\mathrm{F}(12,149)=15.66, \mathrm{R} 2=.56, \mathrm{p}<.01$. This indicated that the predictors all together accounted for a significant amount of variation in the criterion and that together $56 \%$ of the variability of customer satisfaction could be attributed to the predictors. 
Several of the predictors were significant within their model out of them employee fulfillment ( $\beta=$ $-0.29, p<.01$ ) was a negative predictor of customer satisfaction within their model. This indicated customer satisfaction significantly increased with decreasing levels of employee fulfillment. This was statistically significant and not likely due to chance. A t value of -3.54 indicated a statistically significant negative measure of the relationship between employee fulfillment and customer satisfaction. B measured the slope of the line and indicated for every one-unit change in customer satisfaction, employee fulfillment decreased by 0.41 .

Whereas Financial effectiveness $(\beta=0.20, p<.05)$, Process management $(\beta=0.20, p<.05)$, Customer focus $(\beta=0.24, p<.01$, $)$, Employee satisfaction $(\beta=0.26, p<.01)$ were statistically significant positive predictors of customer satisfaction, meaning each of them increased significantly with increasing levels of customer satisfaction within the model and were not likely due to chance. Riccardi, et al. (2009) also reported that the rest predictors such as leadership, continuous improvement, learning, internal/external cooperation, product/service quality, operational efficiency and public responsibility were not significant predictors in their model.

In their model Riccardi, et al. (2009), divided the response variables satisfaction as customer satisfaction and employee satisfaction to perform two multiple linear regression models with both as a response.

Therefore, in their second model they also found similar results with $F(12,147)=13.30, R^{2}=$ $.52, p<.01$ indicating that altogether the predictors accounted for a significant amount of variation in the criterion and that together $52 \%$ of the variability of employee satisfaction could be attributed to the predictors. Several of the predictors were significant. First, employee fulfillment $(\beta=0.33, p<.01)$, Product/service quality $(\beta=0.20, p<.05)$ and were statistically significant positive predictors of employee satisfaction This indicated that employee satisfaction significantly increased with increasing values of those three predictors and were not likely due to chance. The remaining predictors were not significant.

Furthermore, in their study Riccardi, et al. (2009), conducted a simple linear regression model to determine if customer focus was a significant predictor of the level of product/service quality. Their result revealed that customer focus was a significant positive predictor of product/service quality, $F(1,161)=$ $134.71, \beta=0.68, R^{2}=.46, p<.01 . \beta$ showed a positive relationship, meaning that as customer focus increased, and product/service quality increased. Determination of coefficient i.e.; $R^{2}$ indicated that, $46 \%$ of the variability of product service quality was attributed to customer focus. $\mathrm{P}<.01$ indicated that the relationship between customer focus and product/service quality was statistically significant and was probably not due to chance (Riccardi, et al., 2009).

\subsection{Study Populations}

\section{Methodology of the study}

The proposed target population for this study was concentrated on the selective private and governmental TVET colleges of Tigray regional administration, Ethiopia. Particularly, the study population is the 5 private and 5 governmental TVET colleges of eastern zone cluster of Tigray. Therefore, TQM at selective colleges will be checked and analyzed qualitatively and quantitatively.

\subsection{Study Area}

The study entitled the assessment of effective total quality management in case of selective colleges of Tigray regional state was conducted some systematically selected colleges of eastern zone which is one cluster of Tigray. So, the administration of eastern zone is Adigrat town and is located eastern zone of Tigray regional state but the north zone from the view of Ethiopia as whole. Adigrat is $115 \mathrm{~km}$ far from Mekelle which is the capital city of Tigray regional state and around $898 \mathrm{~km}$ far from the Addis Ababa which is the capital city of Ethiopia.

\subsection{Data Sources and types}

For the purpose of this study, both primary source of data and secondary source of data from different documents and files were used. Primary data is the data that either collected by the investigator at first time or it is the original data that collected by different kinds of gathering methods such as, interview telephone or face to face, questionnaire methods, physical observation, experimental test etc.

\subsection{Data collection Methods and Data Gathering Instrument}

For this study self-administered questionnaires and interviews with semi administered questionnaires was used to collect relevant information from selective colleges' management bodies, employees and customers/ students. Furthermore, the review of relevant documents or files, annual abstract and literatures were conducted to have adequate information about the TQM on performances. Focus group discussion was also employed to get the views and opinions of respondents as per necessities. The questionnaires were drafted in English languages with the guidance of the investigator. One important of statistical survey is questionnaire method. The 
simplest definition of questionnaire is that of a group or sequence of question. A designed to elicit information up subject from a respondent's in this study similar questionnaire for all respondents were prepared.

\subsection{Research Design and Method}

Cross-sectional study design was performed in this study by using both qualitative and quantitative research approaches. Therefore, this research with embedded design is employed and both quantitative and qualitative methods of data analysis were used. Information was collected from respondents through questionnaire and analyzed quantitatively using different statistical techniques. Moreover, some Information was collected from various sources through interview, focus group discussion and secondary source to analyze qualitativelythrough narration of information. Accordingly, a qualitative data is embedded within a quantitative methodology. Because of its relevance, content analysis design used to collect the quantitative data, the major data, and interview were used as a qualitative data, the supportive data, gathering instrument. Beside to this the short training was given to data collectors and the questionnaires were distributed to respondents then collected and returned back to investigator by the well-trained data collectors as per the schedules.

\subsection{Study Variables and descriptions}

3.6.1. Dependent Variables

The dependent variables were: (a) product/service quality, (b) Satisfaction (customer \& Employee), and (f) Performance on management (g) TQM practice. All the mentioned are the indicators of TQM.

\subsubsection{Independent Variables}

The independent variables will be: (a) leadership, (b) continuous improvement, (c) employee fulfillment, (d) cooperation (Internal/External), and (e) customer focus. (f) Age of the college (g) existence of quality improvement counsel $(\mathrm{h})$ type of the college

Through the use of inferential statistics, the researcher used the associational approach to explore the relationships between the dependent and independent variables and see what variables were statistically significant predictors of the response variables under the study.

\subsection{Sample size determinations}

Taking sample size have a great advantage over census in different studies to eliminate the wastage of time as well as cost and resources; therefore, the investigators always take a sub-part of populations which must represents the information of populations as whole. In order to have adequate information to achieve the reasonable results and conclusions it is must to have enough sample size with represents the information of populations as whole. According to the sample size formula published by Dillman (2007), the sample size will be determined.

$$
n=\frac{N * P(1-P)}{(N-1) *\left(\frac{d}{Z_{\alpha} / 2}\right)^{2}+P(1-P)}
$$

Where: $n$ is completed sample size needed for desired level of precision $N$ is total size of population $P$ is chance that any respondent will answer a question the same as any other respondent $d$ is acceptable amount of sampling error (margin error) $Z \alpha / 2$ is statistic associated with the confidence level.

To have maximum sample size $P=0.5, d=0.05$ or $5 \%$ and $\alpha=0.05$ or $5 \%$ level of significance was taken and therefore, $Z_{\alpha / 2}$ will be equal to 1.96 according to standard normal table. The desired total sample size $n$ was proportionally allocated in to strata sample sizes. In this study there will be 10 strata i.e., 5 private and 5 governmental TVET colleges of Eastern zone cluster of Tigray.

Accordingly, to allocate sample size for each stratum the general formula will be used as follows.

$$
n_{h}=\frac{n N_{h}}{N}
$$

Notations: $\mathrm{n}=$ the overall sample size: $n=\sum_{i=1}^{h} n_{h}$

$n_{h}=$ The sample size in each stratum

$N_{h}=$ The total number populations in the $\mathrm{h}^{\text {th }}$ stratum and $N$ is total size of study population in all 10 colleges

\subsection{Data Analysis and Presentation}

On the analysis stage, both quantitative and qualitative data was analyzed independently and mixed at the discussion stage. Some relevant statistical analysis such as Binary logistic and multiple linear regression models were implemented based on the characteristics of data with the help of statisticians. In this study to 
observe and overview, the general features of the data on each variable some descriptive as well as inferential statistics were done. Descriptive statistics is a part of statistics that describes or explains the characteristics of sample data without generalizations or drawing conclusions about the characteristics of populations. The techniques most of in used for describing the characteristics of the sample and the major study variables are displayed in the form of frequency distribution, percentage, proportion, and diagrammatic representation such as bar chart, pie chart etc. Inferential statistics is statistical method deals with making inference or conclusion about population based on data obtained from a limited number of observations that come from the population. Inferential statistics consists of estimation and hypothesis testing. Then with techniques of the different statistical analysis, the research will be conducted. Therefore, some relevant statistical methods for data analysis binary logistic regression and multiple linear regressions were modeled.

\subsubsection{Binary logistic regression models}

Binary logistic regression is one of the statistical models for dichotomous response variables having two categories success or failure, presence or absence or yes or no and forth (Hosmer and Lemeshow, 2000). For response variable $Y_{i}$ are binary outcomes with

$$
\begin{aligned}
& Y_{i}=\left\{\begin{array}{l}
l, \text { ifsuccess }(\text { Yes }) \\
0, \text { iff Failure }(\text { No })
\end{array}\right. \\
& P\left(Y_{i}=l\right)=\pi_{i}=\frac{\exp \left(\beta_{o}+\beta_{1} X_{1 i}+\beta_{2} X_{2 i}+\cdots+\beta_{k} X_{k i}\right)}{1+\exp \left(\left(\beta_{o}+\beta_{1} X_{1 i}+\beta_{2} X_{2 i}+\cdots+\beta_{k} X_{k i}\right)\right.} \quad \text { (Logistic model) } \\
& P\left(Y_{i}=0\right)=1-\pi_{i}=\frac{1}{1+\exp \left(\beta_{o}+\beta_{1} X_{1 i}+\beta_{2} X_{2 i}+\cdots+\beta_{k} X_{k i}\right)}
\end{aligned}
$$

Where, $\beta_{o}$ and $\beta_{i}$ are parameters to be estimated. $\pi_{i}$ isthe probability that $Y_{i}$ equals one as we will see shortly, $\beta_{o}$ is constant (intercept) and $\beta_{i}$ is the regression coefficient(slope), which measures the rate of change in $\pi_{i}$ for a given change in $\mathrm{X}$.

The parameter $\beta_{i}$ determines the rate of increase or decrease in the $S$-shaped Curve. Positive values of $\beta_{i}$ imply that $\pi_{i}$ increases with $\mathrm{x}$, negative values of $\beta_{i}$ imply that $\pi_{i}$ increases when $\mathrm{x}$ decreases. $\beta_{i}=0$ implies no relationship between the explanatory variable $\mathrm{x}$ and the probability of success $\pi_{i}$. The probability that $Y_{i}=l$ relative to the probability that $Y_{i}=0$ is equal to $\frac{\pi_{i}}{1-\pi_{i}}$ which is known as Odds. If the odds are $>1$, then the probability that $Y_{i}=1$ is greater than the probability that $Y_{i}=0$; if the odds are $<1$, then the converse is true. If we take the natural $\log$ of the odds $Y_{i}=1: \ln \left(\frac{\pi_{i}}{1-\pi_{i}}\right)$ which is called Logit. This is the logit transformation or link function that we will term $g(X)$, and which can be modeled against our predictor much more easily as(Hosmer and Lemeshow, 2000):

The ratio of the two odds is called the odds ratio.

$$
g(X)=E\left\{Y_{i}\right\}=\beta_{o}+\beta_{1} X_{1 i}+\beta_{2} X_{2 i}+\cdots+\beta_{k} X_{k i}=\operatorname{logit}\left(\pi_{i}\right)
$$

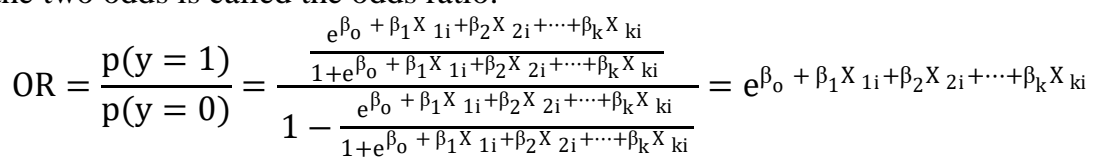

This is telling us that $\beta_{i}$ represents the change in the odds of an outcome for an increase in one unit of X. The constant, $\beta_{0}$, is the value of $g(X)$ when $X_{i}=0$ and represents the intercept of the logistic regression model; its interpretation is similar to the intercept of the linear regression model (Hosmer and Lemeshow, 2000).

\subsubsection{Data Reduction}

In real life it is common to have huge number correlated independent and dependent variables. Hence, it is not easy to manage whole big data and sometimes also many variables are related to each other which lead the analysis to be affected by multi-co-linearity this in turn mislead us to interpret our results in wrong way. Thus, it is important to condense similar variables to one factor (constructs). Consequently, data reduction is the best way for such cases. Data can be reduced by using multivariate statistical techniques so called Principal component analysis (PCA) and factor analysis (FA). In fact, these two techniques can be exploratory in nature; FA is used as a tool in attempts to reduce a large set of variables to a more meaningful, smaller set of variables (Johnston, R., 1978). Beside of this FA is fundamental multivariate model which helps to reduce and condense the data in to simple and manageable form. Furthermore, it is the best tool to detect the multi-co-linearity problems in multiple regressions (Johnston, R., 1978). That's why it is applied in this paper. 


\subsubsection{Multivariate Linear Regression Models}

Multiple linear regressions are the most common form of linear regression analysis. As a predictive analysis, the multiple linear regressions are used to explain the relationship between one continuous dependent variable from two or more independent variables (Agresti, 1990).

$$
\boldsymbol{Y}_{\boldsymbol{i}}=\beta_{o}+\beta_{1} X_{1 i}+\beta_{2} X_{2 i}+\cdots+\beta_{k} X_{k i}+\epsilon_{\boldsymbol{i}}
$$

Where, $Y_{i}$ independent variable/s, $\beta_{i}$ 's are the estimated coefficients or parameters, $X_{k i}$ are fixed known predictors or independent variables and $\epsilon_{i} \sim N\left(\mu, \sigma^{2}\right)$ random errors.

General concepts regressions are: Linear Regression is a process that allows you to make predictions about variable "Y" based on knowledge you have about variable " $\mathrm{X}$ ". The Correlation Coefficient is a single summary number that tells you whether a relationship exists between two or more variables, how strong that relationship is and whether the relationship is positive or negative. The Coefficient of Determination is a single summary number that tells you how much variation in one variable is directly related to variation in another variable. The Standard Error of Estimate is a single summary number that allows you to tell how accurate your predictions are likely to be when you perform Linear Regression (Agresti, 1990).

\subsection{Data descriptions and General Characteristics}

\section{Results and Analysis}

This study generally dealt with assessment of effective TQM on performance at selective colleges in Tigray regional administrative State, Ethiopia. The study is done based on a number of literature studies dealing with (TQM) in general and (TQM) in education and higher education in particular. Cross sectional study design was applied for this careful investigation about effective TQM on performance. Particularly, the study is conducted at TEVT colleges of Eastern Zone of Tigray. Total of 10 colleges such as 5 private and 5 governmental are included in the investigation. The codes were given to each college as GC1-GC5 for governmental and PC1-PC5 for private. In order to have relevant information for investigation two types of well administered questionnaires, one for management body and one for both employees and students/customers were prepared. Accordingly, 7 core management positions or structures such as Dean of College position, Vice Dean level position, Human Resource Manager position, Industry Extension Service position, Registrar director position, Planner position and Finance Director position were taken from each college and the questionnaire was distributed to total of 70 management bodies 7 each from each colleges. Furthermore, the second questionnaire was distributed to sample size of 365 respondents that were selected out of total target population size of 7189 by using probability sampling technique. Stratified sampling technique is used and the sample size was determined for 10 strata by using proportional allocation methods. Under each stratum simple random sampling method was conducted to gather information. Generally, careful and intentional investigation was conducted in this study. After the careful and intentional collection of data the investigator has come up with well-organized methodological and empirical results.

Unlike many literatures included in this paper, this study incorporated the opinions from different stakeholders. However, most investigators incorporated exclusively opinion of management bodies particularly president of the higher education institutes as was shown in most literatures in this study. Unlikely, in this case, a sample of all stakeholders in the college were permitted to participate in the study.

\subsubsection{Descriptive Characteristics of the Results for All Stakeholders}

Results of this study are based on the objectives and analysis of the sample answers of the respondents from each college for both management and other stakeholders. The result incorporated both descriptive and inferential statistics accompanied by empirical analysis and are organized in respective tables. The careful interpretations, discussions and conclusions were conducted.

Some descriptive characteristics with respective frequencies and percentages of each respondent are listed in table 4.1. Accordingly, out of total 365 sample size, $137(37.5 \%)$ of private and $228(62.5 \%)$ were included in the study. Out of total sample 365 the opinion of 122(33.4\%) females and 243(66.6\%) male respondents were included in the study. Moreover, out of total 365 respondents, 333(91.2\%) students and $32(8.8 \%)$ employees have given their opinion in the questionnaire of this study survey. For more details, please refer to table 4.1 .

Table 4.2 refers the counts and percentages of each respondent with their respective positions in their colleges. For instance, total of 204(55.9\%) students from governmental colleges and 129(39.3\%) students from private college as well as 24(6.6\%) employees from governmental and 8(2.2\%) employees from private college were include in the study to give their opinion about TQM in their college. For further details, refer to table 4.2.

According to table 4.3, the description of opinion of respondents on two response variables practice of TQM and product and/or service quality in the college are indicated. Based on the results indicated in table 4.3, out of total 365 sample of respondents, 113(31\%) reported that there is no practice of TQM in their colleges 
whereas, $252(69 \%)$ of them provided their opinion as their colleges practice TQM. Furthermore, according to the particular colleges, 48(13.2\%) from total sample of respondents and 35\% out of 137 from private colleges have reported that their college does not practice TQM anymore. Unlikely, 89(24.4\%) of 365 and $65.0 \%$ out of 137 respondents in private colleges have reported that their college does practice TQM. Similarly, 65(17.5\%) out of total 365 respondents and $28.5 \%$ out of 228 of governmental colleges have reported that their college does not practice TQM anymore. However, 163(44.7\%) of total 365 respondents and $71.5 \%$ out of 228 have reported that their college practices TQM.

Finally, the result indicates that both type of colleges practice TQM well and it is more practiced in governmental than private one. Please refer to table 4.3 for more details.

Beside to results of practice of TQM in colleges, the results based on opinion of the respondents towards product and/or service quality which is one indicator of TQM is also reported in table 4.3. Accordingly, $63(17.3 \%)$ of total 365 respondents and also $46 \%$ out of 137 that are respondent from private colleges have reported that their college has no quality in product and/or service whereas, 74(20.3\%) of total respondents 365 and $54 \%$ out of 137 respondents of private colleges have reported that their college has quality of product and/or service.

Likewise, 101(27.7\%) out of total respondents taken in this survey and $44.3 \%$ out of the respondents taken from governmental colleges have reported that there is no product and /or service quality in their colleges. Whereas, $127(34.8 \%)$ out of total respondents and $55.7 \%$ out of the 228 that was taken from governmental college have reported that there is no quality on product and/or service of their colleges. Generally, 164(44.9\%) of total respondents out of 365 were report that there is no product and/or service quality in their colleges whereas more than of half $201(55.1 \%$ ) out of 365 respondents were report that there is quality on product and/or service in their respective colleges.

Finally, it can be concluded that the quality of product and/service is not enough in both colleges as result indicates almost half- half of yes and no answers. Please refer to table 4.3 for more details.

According to the results listed in table $4.4,122(33.4 \%)$ of total 365 or $89.1 \%$ of 137 of respondents from private college were report that their college has no continues improvement whereas $15(4.1 \%)$ of total 365 and 10.9 of 137 of them were report that their colleges have continues improvement in their progress. Similar to the private college, the report of respondents from governmental colleges has shown that $214(58.6 \%)$ of total 365 or $93.9 \%$ of 228 are believed that their colleges do not have any continues improvement in progress. Whereas, $14(3.8 \%$ ) of total 365 or $6.1 \%$ of 228 were report that their college do have continues improvement in their progress. Generally, $336(92.1 \%)$ of 365 respondents believe that their college do not have any continues improvement in progress whereas $29(7.9 \%)$ of them believe in contrast.

Additionally, $83(22.7 \%$ ) of total 365 or $60.6 \%$ of 137 respondents from private college were report that their colleges do not have internal/external cooperation in their progresses. While, 54(14.8\%) of total 365 or $39.4 \%$ of 137 respondents of them believe that their colleges do have internal/external cooperation in their progresses. In the same way, $120(32.9 \%)$ of total 365 or $52.6 \%$ of 228 respondents of governmental colleges believe that their colleges do not have any cooperation in progress. While, 108(29.6\%) of total or $47.4 \%$ of 228 of them do believe that their colleges do have internal/external cooperation.

Generally, 203(55.6\%) of total 365 of the respondents do believe that their college do not have any cooperation. While, 162(44.4\%) of them do believe that their college do have cooperation in their progresses.

Moreover, 44(12.1\%) of total 365 or $32.1 \%$ of 137 respondents of private colleges did report that their colleges do not have quality improvement counsels. Whereas, 93(25.5\%) of total 365 or $67.9 \%$ of 137 respondents of them were respond as their college do have quality improvement counsels. Likewise, $70(19.2 \%)$ of total 365 or $30.7 \%$ of 228 respondents from governmental colleges describe that their college do not have quality improvement counsels. While, $158(43.3 \%)$ of total 365 or $69.3 \%$ of 228 of them mentioned that their college do have quality improvement counsels.

Gradually, of total 365 respondents $114(31.2 \%)$ of them reported that their colleges do not have quality improvement counsels. While 251(68.8\%) of them agreed that their colleges do have quality improvement counsels. For more details, take look in table 4.4.

The descriptive characteristics about the opinions of respondents towards implementing leadership and employee fulfillment situations are displayed in table 4.5. Accordingly, out of total maximum number of respondents that are about $47(12.9 \%$ ) of total 365 or $34.3 \%$ of 137 from private colleges mentioned that the kind of leadership implementing in their colleges is clarity of vision and the minimum that are $18(7.1 \%)$ of total or $19.0 \%$ of 137 of them mentioned that their colleges use employee empowerment kind of leadership. Likewise, maximum number that are $79(21.6 \%)$ of total 365 or $34.6 \%$ of 228 respondents of governmental colleges responded that the implementing leadership in their colleges is clarity of vision. While, the minimum number $23(6.3 \%)$ of total 365 or $10.1 \%$ of 228 of them responded that their colleges follow plan and implementation change leadership system. 
Moreover, in both private and governmental colleges most respondents mentioned that the employee fulfillment in their colleges is partially full and complete. As the result indicated in table 4.5, 62(17\%) of total 365 or $45.3 \%$ of 137 for private colleges and 114(31.2\%) of total 365 or 50\% of 228 for governmental colleges the employee fulfillment is partially full. Whereas, some of them reported that there is deficiency of employee in their colleges. For more details, take look in table $4.5{ }^{1}$

\subsection{Results of Binary Logistic Regression}

As it was explained in methodological part of this paper, binary logistic regression is one of the statistical models for dichotomous response variables having two categories either success or failure, presence or absence or yes or no and forth.

Research Question:Do Presence of Practice of TQM and product/service quality have any relation with independent variables type of college, period of working experience of the college, kind of leadership, continues improvement, internal/external cooperation, availability of quality improvement counsel and employee fulfillment? To address the above question hypothesis testing plays great role by putting two tentative claims called null and alternative hypotheses as below.

Null hypothesis $\boldsymbol{H}_{\mathbf{0}}: \mathrm{TQM}$ practice or product/service quality has no association with all independent variables. $\mathbf{H}_{\mathbf{0}}: \beta_{\mathrm{i}}=0\left(\right.$ odds ratio $\left.\frac{\pi(\mathrm{x})}{1-\pi(\mathrm{x})}=1\right)$

Which implies $P$ (PresenceofTQMpractice/Yesproduct/service quality/Yes) or is the same at each level of independent variable

Alternative hypothesis $\boldsymbol{H}_{\boldsymbol{A}}$ : Presence of Practice of TQM or product/service quality has association at least with one independent variable. $\beta_{\mathrm{i}} \neq 0$ (odds ratio $\left.\frac{\pi(\mathrm{x})}{1-\pi(\mathrm{x})} \neq 1\right)$

Even though the reference level is chosen by default to be the largest number by SPSS for indicator/dummy variables, in this paper it was adjusted to take the smallest valued category or level as a reference. In this analysis there is no continuous variable included in the model. Hence, it is must to create dummy/indicator variable for all independent variables. Most time people misled in interpreting categorical predictors as they interpret in similar way to continues predictors and that is very serious mistake. Thus, the interpretation should be taken relative to reference level for every dummy variable.

According to the results displayed in table 4.6, the existence of TQM practice is positively associated with all independent variables except employee fulfillment dummy variable two, this is "employee is complete" relative to the reference level "employee is not full" which is negatively related with TQM practice. Furthermore, except three dummy variables i.e., period(2) which is long period of experience of the colleges $(P-$ value $=0.084)$, availability of internal/external cooperation(Yes) $(P-$ value $=0.417)$ and quality improvement counsels(Yes) $(P-$ value $=0.192)$ all have statistically significant associated with existence of TQM practice.

Furthermore, the odds of Practice of TQM is 2.52(52\%) most likely existed in governmental college $\left(\beta_{1}=0.924(0.352)\right)$ relative to private college. The coefficient parameters also provide us similar conclusions. Hence, the coefficient 0.924 indicated that, the presence of TQM Practice is 0.924 times higher in governmental than private college. Moreover, TQM is $1.150(0.335)$ times highly practiced in medium period experienced colleges than short experienced (baseline/reference level). Likewise, it is 0.942 time more practiced in long period experienced than short experienced one. Besides, the odds of Practice of TQM are $3.158(15.8 \%)$ and $2.566(56.6 \%)$ times most likely existed in the colleges which have medium and long period work experiences respectively.

Additionally, TQM practice is $0.931(0.403)$ times higher in the colleges those implementing Clarity of vision leadership system relative to the colleges those "plan and implement change" leadership system is being implemented which was reference level. Likewise, similar conclusions can be taken by using the odds ratios. Thus, the odds of Practice of TQM is 3.794(79.4\%) times most likely practiced in the colleges those encourage employee empowerment leadership than "plan and implement change" leadership system is being implemented. The rest dummy variables could be interpreted in similar ways.

Furthermore, TQM practice is $1.156(0.561)$ times more existed in the colleges those continues improvement is being available relative to not available. Likely, the independent variable continuous improvement $(P-$ value $=0.039)$ has statistically significance positive relationship with TQM practice at 5\% level of significance. Thus, there is $95 \%$ evidence to reject null hypothesis in favor of alternative hypothesis.

${ }^{1} \mathrm{NB}: \mathrm{EMF}=$ Employee fulfillment, $\mathrm{KOL}=$ kind of leadership, $\mathrm{CV}=$ Clarity of Vision, LRO= long-range orientation, $\mathrm{CMS}=$ coaching management system, $\mathrm{EMEMP}=$ Employee empowerment and $\mathrm{PIC}=\mathrm{Plan}$ and implementation Change. 
So, the odds of Practice of TQM is $3.176(17.6 \%)$ times most likely practiced in the colleges those encourages continuous improvement relative to do not have continuous improvements. Based on the $95 \%$ confidence intervals for odds ratio $(1.057,9.538)$ also it can be concluded that since the interval does not include 1 , it indicated there is statistically significant effect on TQM that caused by presence of continuous improvement. There for the null hypothesis that says there is no relationship between TQM and Continuous improvement is rejected in favor of the alternative hypothesis.

In addition to that, the coefficient 1.646(0.639) indicated that TQM practice is 1.646 times higher than in the colleges with partially full employees relative to the reference level "not full". Whereas, the coefficient of complete employee fulfillment -1.029(0.266) indicated that TQM practice is 1.029 times lower in the colleges with complete employee relative to "not full."

Generally, the Wald Z- test shows that the large Wald test statistics values associated to small P-values provide us more evidence of rejecting the null hypothesis that says all coefficients are equal to zero or all the odds of interested and baseline/ reference levels are equal that means in short odds ratios are equal to one. The smaller standard errors (S.E) values refer better precisions and accuracy of estimations and higher standard errors (S.E) values in opposite senses. Here the insignificant results may not interpreted because no need to interpret statistically insignificant results. For more details please take look in table 4.6.

According to the results displayed in table 4.7, the existence of product/service quality is positively associated with all independent variables except two dummy variables medium period of work experience of the colleges $(-0.266(0.282))$ relative to the reference level i.e.; "short period of work experience" and employee fulfillment dummy variable two, this is employee is complete $(-0.127(0.238))$ relative to the reference level "employee is not full" which are negatively related with it.

Furthermore, except three variables i.e.; leadership with dummy variables long-range orientation, coaching management style and Clarity of vision ( $\mathrm{P}$-values $=0.024,0.007,0.014)$ respectively, continuous improvement $(\mathrm{P}$-value $=0.035)$ and employee fulfillment with dummy variable partially full $(\mathrm{P}$-value $=0.040)$ are statistically significant relative to their respective reference levels Plan and implement change, No, and not full respectively all the rests are statistically insignificant or there is no evidence to reject the null hypotheses that says there are no relationship among product/service quality and these independent variables having small Wald test statistics (Z-test) values associated with large p-values.

Additionally, the coefficient or parameter of Clarity of vision i.e.; 0.915 (0.372) indicated that product/service quality is 0.915 times higher in the colleges having Clarity of vision leadership system relative to reference level which is the colleges those "plan and implement change" leadership system is being implemented. Likewise, similar conclusions can be taken by using the odds ratios. Thus, the odds of availability of product/service quality is $3.198(19.8 \%)$ times most likely practiced in the colleges those encourage coaching management style leadership than reference level that is "plan and implement change" leadership system is being implemented. The rest dummy variables could be interpreted in similar ways.

Furthermore, product/service quality is $0.876(0.415)$ times higher in the colleges those continues improvement is being available relative to not available. Likewise, the independent variable continuous improvement $(P-$ value $=0.035)$ has statistically significance positive relationship with product/service quality at $5 \%$ level of significance. Thus, there is $95 \%$ evidence to reject null hypothesis in favor of alternative hypothesis. So, the odds of product/service quality are $2.400(40 \%)$ times most likely available in colleges those encourage continuous improvement relative to do not have continuous improvements. Based on the $95 \%$ confidence intervals for odds ratio $(1.064,5.413)$ also it can be concluded that since the interval does not include 1 , it indicated there is statistically significant effect on product/service quality that caused by presence of continuous improvement. There for the null hypothesis that says there is no relationship between product/service quality and Continuous improvement is rejected in favor of the alternative hypothesis.

In addition to that, the coefficient $0.723(0.351)$ indicated that product/service quality is 0.723 times higher than in the colleges with partially full employees relative to the reference level "not full". Whereas, the coefficient of complete employee fulfillment $-0.127(0.238)$ indicated that product/service quality is 0.127 times lower in the colleges with complete employee relative to "not full."

Generally, the Wald Z- test shows that the large Wald test statistic values associated to small P-values provide us more evidence of rejecting the null hypothesis that says all coefficients are equal to zero or all the odds of interested and baseline/reference levels are equal that means in short odds ratios are equal to one. In addition to this the values in bracket with coefficients are the standard errors indicating the precision of the estimation of the parameters and coefficients. The smaller standard errors (S.E) values refer better precisions and accuracy of estimations and higher standard errors (S.E) values in opposite senses. Here the insignificant results may not interpreted because no need to interpret statistically insignificant results. For more details please take look in table 4.7 .

The right side values of results in table 4.8, refers to the results related Product/Service Quality whereas, left side refers to the values related to TQM. According to the results displayed in the table, Omnibus 
Tests of Model Coefficients $\left(X_{12}^{2}=78.8(P-\right.$ value $\left.<0.001)\right)$ for presence of TQM practice in the college indicated that the overall model is statistically significance; whereas, the right side results of table have shown that, there is no enough evidence of statistical significance of the overall binary logistic regression model $\left(X_{12}^{2}=19.813(P-\right.$ value $\left.=0.071)\right)$ at $5 \%$ level of significance. In addition to that, the Hosmer-Lemeshow Goodness-of-Fit Test for both models with HL statistic $\left(X_{8}^{2}=12.001(P-\right.$ value $\left.=0.151)\right)$ and $\left(X_{8}^{2}=\right.$ $3.861(P-$ value $=0.869))$, led us to do not reject the null hypothesis that says there is no difference between the observed and predicted values or the model is inadequate for the data; indicating that the both logistic regression models are good fit to the data.

\subsection{Results and Discussions of Management Body's Data \\ 4.3.1. Factor Analysis for Data Reduction}

In real life it is common to have huge number correlated independent and dependent variables. Hence, it is not easy to manage whole big data and sometimes also many variables are related to each other which lead the analysis to be affected by multi-co-linearity this in turn mislead us to interpret our results in wrong way. Thus, it is important to condense similar variables to one factor (constructs). Consequently, data reduction is the best way for such cases. Data can be reduced by using multivariate statistical techniques so called principal component analysis (PCA) and factor analysis (FA). In fact, these two techniques can be exploratory in nature; FA is used as a tool in attempts to reduce a large set of variables to a more meaningful, smaller set of variables.

Beside of this FA is fundamental multivariate model which helps to reduce and condense the data in to simple and manageable form. Furthermore, it is the best tool to detect the multi-co-linearity problems in multiple regressions. That's why it is applied in this paper.

In our case, the data for management body were collected based on total of 20 independent variables and 9 dependent variables. All variables are displayed in the appendix $\mathrm{C}$ of this paper. Finally, the correlations of original variables were checked and similar factors were grouped in to particular categories by using factor analysis. Even though it is not displayed in this paper as it was huge table, the correlations among original independent factors as well as dependent variables were statistically significant. The twenty (20) independent variables/factors were condensed in to five (5) components/factors and nine (9) dependent variables were also condensed in to two (2) components/factors with reasonable inter-correlations and communalities among them.

The total variances explained by latent independent variables/constructs of TQM are displayed in the table 4.9. Hence, $70.393 \%$ of the variability are explained or covered by five latent components/factors such as leadership, Continues Improvement, Employee Fulfillment, Internal or External Cooperation and Customer Focus however, the rest $29.607 \%$ are explained by others. These variables are so taken as the independent/explanatory variables for multiple regression models to check the relationship of constructs of TQM.

Similarly, $76.842 \%$ of variability is explained by two latent components/factors such as product/service quality and satisfaction of employee and customers whereas the rest $23.158 \%$ are explained by the rest factors as shown in table 4.9. Hence, these two latent variables are considered as the dependent or response variables of TQM constructs in multiple regressions which are shown in later below in this paper. Thus, it is reasonable to condense the huge variables in to five independent latent variables and two latent response/dependent variables.

Generally, in factor analysis for data reduction principal component analysis technique as an extraction method and most commonly used rotation method of Varimax with Kaiser Normalization were used by SPSS and the result is displayed in table C.2 and C.3.

The descriptive statistics of the all original variables are also displayed in the appendix. For further details refer to table C.1.

\subsubsection{Multiple Linear Regression Models}

In general multiple linear regressions are the most common form of linear regression analysis. As a predictive analysis, the multiple linear regressions are used to explain the relationship between one continuous dependent variable from two or more independent variables. The independent variables can be continuous or categorical (dummy coded as appropriate). In this case the dependent variables are continuous variables which are the loads of the factor scores of factor analysis results. In this paper two continuous latent responses and 5 continuous latent independent variables are included after the systematic reduction of data. Thus, the results of multiple regression models with latent responses satisfaction and product/service quality are displayed in table 4.11 and 4.12 respectively.

\section{Questions:}

1. Is there relationship between satisfaction and five latent covariates?

2. Is there relationship between product/service quality and five latent covariates? 
To test these two questions it is obvious to use some hypothesis. In general, it is common to deal with two tentative hypotheses i.e.; null and alternative hypotheses.

Null hypothesis for first question: Satisfaction has no relationship with independent variables. $H_{0}: \beta_{0}=\beta_{1}=$ $\beta_{2}=\beta_{3}=\beta_{4}=\beta_{5}=\beta_{6}=0$ or $\left(\beta_{i}=0, i=1, \ldots, k\right)$

Alternative hypothesis: Satisfaction has relationship with at least one of independent variables. $H_{A}: \beta_{0} \neq \beta_{1} \neq$ $\beta_{2} \neq \beta_{3} \neq \beta_{4} \neq \beta_{5} \neq \beta_{6} \neq 0$ or $\left(\beta_{i} \neq 0, i=1, \ldots, k\right)$

According to the results of multiple regression model for satisfaction displayed in table 4.11 , out of total 6 independent variables three of them are statistically insignificant indicating there is no evidence to reject the null hypothesis that says there is no significant relationship between level of satisfaction and college type (Governmental) $(\mathrm{P}$-value $=0.972)$, cooperation $(\mathrm{P}$-value $=0.310)$ and customer focus $(\mathrm{P}$-value $=0.807)$ at $5 \%$ level of significance respectively. Whereas the rest three independent variables such as leadership (P-value $=0.003)$, continuous improvement $(\mathrm{P}$-value $=0.001)$ and employee fulfillment (P-value $<0.001)$ have statistically significant relationship with level of satisfaction in the model, therefore, there is enough evidence to reject the null hypothesis stated above at $5 \%$ level of significance.

Moreover except college type $\left(\beta_{1}=-0.006(0.159)\right)$ indicated negative relationship all the rest variables are positively related with level of satisfaction. So, the negative coefficient or parameter of college type indicated that, the level of satisfaction for employees and customers are 0.006 times lower in governmental college than private college.

The coefficient of leadership $\left(\beta_{2}=0.249(0.079)\right)$ indicated that, the rate amount of the level of satisfaction is 0.249 times increases per a unit increase in leadership keeping all the other variables constant. Similarly, the coefficient of continuous improvement $\left(\beta_{3}=0.274(0.079)\right.$ refers, the level of satisfaction increases by the amount of 0.274 per a unit increase on continuous improvement assuming all the rest variables hold constant. Likewise, the coefficient of Employee fulfillment $\left(\beta_{4}=0.681(0.078)\right)$ denoted that, a unit increase on level of employee fulfillment causes 0.681 times increase on the level of satisfaction if all the rest variables hold constant.

Generally, the variable with the large t-test statistic value accompanied with small p-values indicates the statistically significant relationship of latent response variable (level of satisfaction) and independent variables. Likewise, $95 \%$ confidence intervals displayed at the right side column of table 4.11, could provide us similar conclusions. The $95 \%$ confidence intervals for leadership $(0.090,0.407)$, for continuous improvement $(0.115,0.432)$ and for employee fulfillment $(0.525,0.838)$ have excluded zero in the intervals indicating the rejection of null hypothesis stated in the above in favor of the alternative one. However, the $95 \%$ confidence intervals of the rest three independent variables have included zero in the intervals indicating that there is no evidence to reject the null hypothesis.

Furthermore, correlation coefficient which is the measure of strength of relationship and determination of coefficient which is measure of variability explained by the model or by the predictors/independent variables or by the data as whole are displayed in table 4.11. Accordingly, correlation coefficient $(r=0.783)$ indicated that there is strong positive relationship between latent response level of satisfaction and independent variables. Similarly, the determination of coefficient $\left(R^{2}=0.614\right)$ shows, the $61.4 \%$ of the variability is explained or caused by the data in model. In short, $61.4 \%$ of variability in the level of latent response satisfaction is explained by the predictors/independent variables. This also measures the goodness of fit of the model. So, it indicated that the linear regression model is well fit.

Finally, the result of ANOVA for multiple regression displayed in table 4.11, indicated that the overall multiple regression model is statistically significant with (p-value $<0.001$ ). Gradually, the values appeared in the bracket with coefficients everywhere in this paper are standard errors and are measures of precision, accuracy and consistency of the estimated results. The small values of standard errors tell us the estimations are good and large standard errors tell us the reverse.

${ }^{2}$ Null hypothesis for Second question: Products/service quality has no relationship with predictors. $\mathrm{H}_{0}: \beta_{0}=$ $\beta_{1}=\beta_{2}=\beta_{3}=\beta_{4}=\beta_{5}=\beta_{6}=0$ or $\left(\beta_{\mathrm{i}}=0, \mathrm{i}=1, \ldots, \mathrm{k}\right)$

\footnotetext{
${ }^{2}$ Note: The P-Values of less than $5 \%$ indicate the significant relationship of the dependent and independent variables. Similarly, if the $95 \%$ Confidence interval for odds ratios exclude 1 inside the interval it shows significant relationships unless shows statistically insignificant results.
} 
Alternative hypothesis:Products/service quality has relationship with at least one of predictor. $\mathrm{H}_{\mathrm{A}}: \beta_{0} \neq \beta_{1} \neq$ $\beta_{2} \neq \beta_{3} \neq \beta_{4} \neq \beta_{5} \neq \beta_{6} \neq 0$ or $\left(\beta_{\mathrm{i}} \neq 0, \mathrm{i}=1, \ldots, \mathrm{k}\right)$

According to the results of multiple regression model for latent response variable products/service quality displayed in table 4.12, out of total 6 independent variables two of them are statistically insignificant indicating there is no evidence to reject the null hypothesis that says there is no relationship between products/service quality and college type (Governmental) $(\mathrm{P}$-value $=0.799)$, customer focus $(\mathrm{P}$-value $=0.266)$ at $5 \%$ level of significance. Whereas the rest four independent variables such as leadership ( $\mathrm{P}$-value $<0.001)$, continuous improvement (P-value=0.001), employee fulfillment (P-value <0.001) and cooperation (Pvalue $=0.035$ ) have statistically significant relationship with level of product/service quality in the model; therefore, there is enough evidence to reject the null hypothesis stated above at $5 \%$ level of significance.

Moreover, except college type $\left(\beta_{1}=-0.045(0.175)\right)$ and also surprisingly customer focus $\left(\beta_{6}=\right.$ $0.095(0.085)$ ) indicated negative relationship, all the rest variables are positively related with level of product/service quality. So, the negative coefficient or parameter of college type indicated that, the level of product/service quality is 0.045 times lower in governmental college than private college. Similarly, the negative coefficient of level of customer focus indicated that, the level of product/service quality declined by 0.095 per unit increase on level of customer focus.

The coefficient of leadership $\left(\beta_{2}=0.413(0.105)\right)$ indicated that, the rate amount of level of products/service quality increases by rate of 0.413 per a unit increase in level of leadership if all the other variables kept constant. Similarly, the coefficient of level of continuous improvement $\left(\beta_{3}=0.285(0.086)\right.$ refers, the level of product/service quality increases by the amount of 0.285 per a unit increase in continuous improvement assuming all the rest variables hold constant. Likewise, the coefficient of employee fulfillment $\left(\beta_{4}=0.663(0.085)\right)$ denoted that, a unit increase on employee fulfillment causes 0.681 times increase on the product/service quality if all the rest variables hold constant. The coefficient of cooperation $\left(\beta_{5}=\right.$ $0.226(0.105)$ ) also indicated that, a unit increase on cooperation causes 0.226 times increase on the level of product/service quality if all the rest kept constant.

Generally, the variable with the large test statistic value which is t-values accompanied with small pvalues indicates the statistically significant relationship of latent response variable (level of product/service quality) with independent variables. Likewise, $95 \%$ confidence intervals displayed at the right side column of table 4.12, could provide us similar conclusions. The $95 \%$ confidence intervals for leadership $(0.203,0.623)$, for continuous improvement $(0.114,0.456)$, for employee fulfillment $(0.494,0.833)$ and for cooperation $(0.016$, 0.436) have excluded zero in the intervals indicating the rejection of null hypothesis stated in the above in favor of the alternative one. However, the $95 \%$ confidence intervals of the rest two independent variables have included zero in the intervals indicating that there is no evidence to reject the null hypothesis.

Furthermore, correlation coefficient which is the measure of strength of relationship and determination of coefficient which is measure of variability explained by the model or by the predictors/independent variables or by the data as whole are displayed in table 4.12. Accordingly, correlation coefficient $(r=0.741)$ indicated that there is strong positive relationship between latent response variable level of satisfaction and independent variables.

Similarly, the determination of coefficient $\left(R^{2}=0.549\right)$ shows, the $54.9 \%$ of the variability is explained or caused by the data in model. In short, $54.9 \%$ of the latent response/dependent variable level of product/service quality is explained by the predictors/independent variables. This also measures the goodness of fit of the model. So, it indicated that the regression model is fair fit.

Finally, the result of ANOVA for multiple regression displayed in table 4.12, indicated that the overall multiple regression model is statistical significant with ( $p$-value $<0.001)$.

Gradually, the values appeared in the bracket with coefficients everywhere in this paper are standard errors and are measures of precision, accuracy and consistency of the estimated results. The small values of standard errors tell us the estimations are good and large standard errors tell us the reverse. Furthermore, the standard errors are very important to calculate confidence intervals and estimate coefficients in the model.

Finally, multiple linear regression models for both latent response variables which are the constructs of TQM showed that there are enough association among the latent dependent variables/constructs of TQM and latent independent variables/constructs of TQM.

\section{Discussions}

Based on different well organized literatures and analysis that were included in this thesis, some discussions and review of works are organized as following.

This study was conducted on the title, assessment of the Effective total quality management on performance at selective colleges in Tigray regional administrative State, Ethiopia. Particularly, it was concerned with TEVT colleges of eastern zone of Tigray regional state. In summary, the study dealt with TQM 
on performanceand was done based on a number of literature studies dealing with (TQM) in general and (TQM) in education and higher education in particular.

The study was organized by referring the standard of international standardization Organization (ISO 9001), Six Sigma and the Malcolm Baldrige National Quality Award. The constructs of TQM were designed in line to those standards by reviewing some literatures mentioned in chapter two of this paper.

The good idea of this paper is unlike most of literatures it was not focused only on the opinion of president/dean of the colleges rather included the opinion of the other stakeholders like students/customers and employees of the colleges in order to get the feedback from both sides. This could reduce and compensate the biases due to the solely responses of leading body.

In some literatures the Cronbach's alpha reliability test was performed on all TQM constructs by Hoang D.T. et al., (2010), to assess the reliability of the collected data. Whereas in this paper even though the reliability was checked, the results of Cronbach's alpha were not included. Multiple linear regression for management data and binary logistic regressions for data that collected from sample of all stakeholders were performed to assess the associations of some TQM constructs.

Unlike some literatures included that many constructs of TQM variables such as appeared in this paper, this study excluded some variables that are constructs of TQM because of some constraints. For instance, Riccardi, et al. (2009) in their dissertation paper entitled "Perceptions of community college presidents: total quality management performance measures at their colleges", they included variables, learning, process management, operational efficiency, public responsibility, financial effectiveness, leadership, continuous improvement, internal/external cooperation, customer focus, employee fulfillment, customer satisfaction, employee satisfaction, product/service quality whereas in this paper only some of the constructs of TQM were included.

In short the study covered only some latent constructs of TQM that are five independent and two dependent latent variables after the technical and careful reduction of data by using factor analysis methods. Thus, finally, the investigator came up with latent independent variables/constructs of TQM such as leadership, continuous improvement, employee fulfillment, internal/external cooperation and customer focus and latent dependent variables/constructs of TQM so called level of satisfaction and level of product/service quality.

In this paper, unlike paper of Riccardi, et al. (2009) who modeled several multiple regression models with several independent and dependent variables, only two multiple linear regression models with two latent dependent variables level of satisfaction and product quality and five latent independent variables and college type were fitted

According to results of Riccardi, et al. (2009), customer focus was a significant positive predictor of level of product/service quality, $\operatorname{with} F(1,161)=134.71, \beta=0.68, R^{2}=.46, P-$ value $<.01$. However, in contrast to that, in this finding there is statistically negative and insignificant relationship between latent response level of product/service quality and latent predictor customer focus $\left(\beta_{6}=-0.095(0.085), p-\right.$ value $=0.266$.

In this finding, the level of continuous improvement $\left(\beta_{6}=0.249(0.079), \mathrm{P}-\right.$ value $\left.=0.001\right)$ was statistically significant positive latent predictor of latent response level of satisfaction. However, in contrast, it was statistically insignificant predictor (P-value $=0.338$ ) of level of satisfaction (Riccardi, et al., 2009).

Furthermore, Riccardi, et al. (2009) in their findings of multiple linear regression after the reduction of data using factor analysis, they reported that leadership (P-value=0.266) was statistically insignificant in their model showing no relation between leadership and level of satisfaction. Whereas in opposite to that, in this finding leadership is statistically significant latent predictor of latent response level of satisfaction with $p$-value $=$ 0.003 .

Moreover, this finding has shown that, employee fulfillment $\left(\beta_{4}=0.681(0.078), \mathrm{P}-\right.$ value $\left.<0.001\right)$ is statistically significant positive latent predictor of level of satisfaction. This relationship is in line with the research conducted by Riccardi, et al. (2009) that employee fulfillment $(\beta=0.35(0.09), P-$ value $<0.001)$ with employee satisfaction. Likewise, the finding revealed that, there is no statistically significant relationship between latent response variable level of satisfaction and latent predictor internal/external cooperation $\left(\beta_{4}=\right.$ $0.080(0.078), P-$ value $=0.310)$. The finding is consistent with the latest literature Riccardi, et al. (2009) that reported association between predictor internal/external cooperation $(\beta=0.0 .02(0.09), P-$ value $=0.87)$ satisfaction was not significant.

\section{Conclusions and Recommendations}

\subsection{Conclusions}

The main aim of this study was to assess the Effective total quality management on performance at selective colleges in Tigray regional administrative State, Ethiopia particularly, TEVT colleges in eastern zone of Tigray. 
This study investigated whether there is a significant difference in the TQM constructs implemented between private and governmental colleges. The study also elaborated the relationship between level of two latent response variables and five latent independent variables which are in turn indicators of TQM accompanied by type of college. Opinions of management body from 7 core positions or structures in each college were collected. Thus, total of 70 leaders each 7 from each college were questioned about the situations of TQM in their colleges. Two multiple linear regressions with latent response variables level of satisfaction and level of product/service quality were fitted.

Unlike other related literatures this study incorporated several types of opinions from different stakeholder which in turn help to reduce and compensate the response biases that might be occurred from one side stakeholders and these characteristics made this paper somewhat special from others.

Besides of multiple regression models for leaders' opinion, two binary logistic regression models with dichotomous response variables availability of TQM (Yes/No) and product/service quality (Yes/No) were modeled. In this study some documents and reports of each college were reviewed and some physical interviews were also performed. According to interviews, observations and annual and monthly reports of the college, almost more than half of colleges do practice TQM in their management but still not enough in implementations. Some of them also practiced but not successful on it and very few of them totally do not apply. Similar, opinions were reported from the open ended questionnaires.

This paper included several questions with several variables especially in collecting leaders. Therefore, the numbers of huge variables were collected. Gradually, by using multivariate statistical technique so called factor analysis, the huge numbers of variable were reduced and condensed in to only few numbers of latent variables i.e.; five independent and two dependent variables which are the constructs of TQM. As the result for factor analysis in chapter four indicated, out of total 20 variables, $70.393 \%$ of the variability were explained or covered by five latent components/factors such as leadership, Continues Improvement, Employee Fulfillment, Internal or External Cooperation and Customer Focus however, the rest $29.607 \%$ were explained by rests. These variables were so taken as the independent/explanatory variables for multiple regression models to check the relationship of constructs of TQM.

Similarly, out of total of 9 variables, $76.842 \%$ of variability was explained by two latent components/factors such as level of product/service quality and level of satisfaction for employee and customers whereas the rest $23.158 \%$ are explained by the rest factors as shown in table 4.9 . Hence, these two variables were considered as the latent dependent or response variables of TQM constructs in multiple regressions.

Finally, according to results of multiple linear regression models both level of satisfaction and product/service quality had statistically significant positive relationship with leadership, continuous improvement and employee fulfillment. Whereas, surprisingly customer focus was negatively related with level of product/service quality and also it was not significantly associated with both level of satisfaction and product/service quality. This perhaps happened due to the exclusion of some important and relevant variables in the model.

Moreover, according to the results of binary logistic regression model, the existence of TQM practice is positively associated with all independent variables except employee fulfillment dummy variable two "employee is complete" relative to the reference level "employee is not full" which is negatively related with it. Furthermore, except three dummy variables i.e., period(2) which is long period of working experience of the colleges $(P-$ value $=0.084)$, availability of internal/external cooperation(Yes $)(P-$ value $=0.417)$ and quality improvement counsels $($ Yes $)(P-$ value $=0.192)$ all the rest variables have statistically significant association with existence of TQM practice.

Similarly, the existence of level of latent response product/service quality is positively associated with all independent variables except two dummy variables medium period of work experience of the colleges ($0.266(0.282)$ ) relative to the reference level i.e.; "short period of work experience" and employee fulfillment dummy variable two, this is employee is complete $(-0.127(0.238))$ relative to the reference level "employee is not full" which are negatively related with it. Furthermore, except three variables i.e.; leadership with dummy variables long-range orientation, coaching management style and Clarity of vision $(\mathrm{P}$-values $=0.024,0.007$, $0.014)$ respectively, continuous improvement $(\mathrm{P}$-value $=0.035)$ and employee fulfillment with dummy variable partially full $(\mathrm{P}$-value $=0.040)$ are statistically significant relative to their respective reference levels Plan and implement change, No, and not full respectively all the rests are statistically insignificant

Finally, After passing many procedures the results and discussions of this paper elaborated that the strength of the relationship between latent dependent variables level of product/service quality and satisfaction with latent independent variables suggests that TQM practitioners should place more importance on leadership, continuous improvement, internal/external cooperation, employee fulfillment and customer focuses if they wish to see a subsequent increase in product/service quality and satisfaction of employees and customers or students. 
This study was not limited only on statistical evidence but also empirical study was incorporated by reviewing the literatures and related documents of different colleges in order to assess the efficacy and adequacy of TQM on performance.

\subsection{Recommendations}

Based on the results and discussions the following ideas are recommended.

As an appropriate and relevant data directly related to the qualities and nature of the research, in the case of limited quality data, the associations of factors or covariates with outcome variables could not be assessed. Regarding data collection, special efforts are needed to get data of better quality.

The leaders of colleges should update their activities within short time in order to check whether their management system is going in good track or not.

All TQM practitioners should place more emphasis on the performance and implementation than simple draft. So they can evaluate their TQM efficacy and effectiveness on performance.

Generally, continuous evaluation of TQM on performance is highly recommended in order to sustain their implementations.

\subsection{Limitations}

The investigation was intended to identify the relationship of constructs of TQM in brief however; there were a lot of constraints starting form data collection up to the end of the works. Some of them are listed here below:

- As sample size was large enough it was difficult to print, copy, distribute and collect the questionnaire for individual respondents.

- The respondents were not available at exact time and it credits cost and time crisis.

- Some variables were not included in the models due to financial and time constraints and that in turn might have been negative effect in the work.

- Generally these are some of the several constraints and limitations.

\section{Acknowledgement}

First and foremost I must give thanks to almighty God for all the blessings he bestowed upon me till today.Then I want to express my sincere gratitude and appreciation to my advisor his Excellency ZaidNegash (PHD, President of Adigrat University) for his advice and encouragement from inception up to completion.

Secondly my sincere thanks go to my co-advisor Mr. Haftu Girmay (MA) for his excellent advices and guidance in all aspects. Thirdly my heartfelt gratitude and thanks is extended to my department staffs as whole for allowing me to do my MA thesis on this title and also for their good encourage in my course studies.I would like to take this opportunity to express my heartiest appreciation to my beloved brother Yemane Hailu (PHD Scholar of Biostatistics) for his unlimited and insightful guidance, consistent support, and impressive encouragement in this paper work from inception up to completion.Finally, and most importantly my deepest gratitude goes to Aba Tomas Weldesilasie, Mehret Hailu, NiguseKahsay, my mother, my brothers and sisters, TeberihTesfay, TeameHagos and all my friends who were greatly involved in my work in any means. Last but not the least my special thanks go to respondents and college staffs for their kind responses and supports.

\section{Reference}

[1]. Abu nabaa, A., \&Massad, F. (2000). Total quality management in educational Institutions. Journal of Manama, 5, 10-25.

[2]. Agresti, A. (1990). Categorical Data Analysis. New York: Wiley.

[3]. Ahire, L.S., Golhar, D.Y., \& Waller, M.A. (1996). Development and validation of TQM implementation constructs. Decision Sciences, 27, 23-56.

[4]. Al-gmeez, N. (2004). The exactest of applying standards of (TQM) at the ministry of higher education in Saudi Arabia from the perspective of managers and heads of departments. Unpublished MA thesis, Yarmouk University, Irbid, Jordan.

[5]. Ali. M. and Shastri. R. K. (2010). Implementation of Total Quality Management in higher education.Asian Journal of Business Management, 2 (1], pp. 9-16.

[6]. Alkazaz, I. (2001). The practical application of requirements of ISO 2000-9001 for quality system. (pp.129-140), Baghdad: ALashqar for printing.

[7]. Al-Khafaji, A., \&Babairman, S. (1995). Strategic planning and TQM in academic institutions. Journal of Financial and Banking Studies, 2, 99-115.

[8]. Al-Saud, R. (2002). Total Quality Management: A model proposed for the development of school management in Jordan. Journal of the University of Damascus, 18, 63-78.

[9]. Anderson, J., Rungtusanatham, M. \& Schroeder, R. (1994).A theory of quality management underlying the Deming management method. The Academy of Management Review, 19(3), 472-509.

[10]. Anderson, J.C., \& Gerbing, D.W. (1988). Structural equation modeling in practice: A review and recommended two-step approach. Psychological Bulletin, 103, 411-423.

[11]. Ani, K. (2002).TQM and the requirements of ISO 9000. (1st ed). Baghdad: Alshagar Press.

[12]. Arjomandi, M., C. Kestell and P. Grimshaw. 2009. An EFQM Excellence Model forhigher education quality assessment. [online] [Accessed 14 October 2010], Available from: http://www.google.co.uk/search?sourceid=navclient\&ie=UTF8\&rlz=1T4SKPB_ enGB39 2GB93\&q=An+EFQM+excellence+modle+for+higher+education+quality+assessment. 
[13]. Ayoub, A. (2000). The effectiveness of the use of Total Quality Management in the Development of the Performance of the Jordanian Universities.Unpublished MA thesis, Yarmouk University, Irbid, Jordan.

[14]. Barnett, R. (1992). Improving Higher Education. Suffolk: St Edmundsbury Press Limited.

[15]. Burkhalter, B.B. (1996). How can institutions of higher education achieve quality within the new economy? Total Quality Management, 7(2), 153-160.

[16]. CEPES. (2009). UNESCO Forum on Higher Education in the Europe Region: Access, Values, Quality and Competitiveness. [online] [Accessed 03 December 2010] Available from: http://www.cepes.ro/forum/pdf/welcomenote.pdf.

[17]. Cornesky, R. (1994). Using Deming to improve Quality at Colleges and Universities. New York: man publications.

[18]. Dagher, M. (2001). Total quality management strategy: an approach to the development of higher education in the Arab world. Paper presented at the first Arab Thought Forum: international standards for Universities. July 24-26, 2001. Baghdad, Iraq.

[19]. Damtew T. (2005) Private Higher Education in Ethiopia: The Current Landscape

[20]. Daradkeh, M., \&Shibli, T. (2002).Quality at modern organizations. Amman: Dar Safa for printing.

[21]. Decosmo, R. (1991). Total quality managements in higher education. San.Francisco, CA: Jossey Bass

[22]. Dillman, D.A. (2007). Mail and internet surveys: The tailored design method (2nd ed.). Hoboken, NJ: John Wiley \& Sons.

[23]. Frazier, A. 1997.A roadmap for quality transformation in education. Boca Raton, Fla.: St. Lucie Press.

[24]. Grandzol, J.R. \&Gershon, M. (1997). Which TQM practices really matter: An empirical investigation. Quality Management Journal, 4(4), 43-59.

[25]. Grandzol, J.R. \&Gershon, M. (1998).A survey instrument for standardizing TQM modeling research. International Journal of Quality Science, 3(1), 80-105.

[26]. Gueorguie, T. (2006), Quality Management in Higher Education

[27]. Gupta, S. K. (1993). Quality Improvement in Teaching.Explorations in Teaching andLearning.3(3], pp. 4-5

[28]. Hair, J.F., Anderson, R.E., Tatham, R.L., \& Black, W.C. (1998).Multivariate data analysis. Upper Saddle River, NJ: Prentice-Hall International Inc.

[29]. Harvey, L. and A. Burrows, 1992. „Empowering studentse', New Academic.1(3]: pp. 2-3.

[30]. Ho, S.K., \&Wearn, K. (1995). A TQM model for higher education and training.Training for Quality, 3(2), 25-33.

[31]. Hoang D.T. et al., (2010). Total quality management (TQM) strategy and organizational characteristics: Evidence from a recent WTO member a University of Economics, Hochiminh City, Vietnam; ${ }^{\text {b}}$ School of Management, Asian Institute of Technology, Pathumthani 12120, Thailand; 'Industrial Engineering Department, Faculty of Engineering, Thammasat University, Pathumthani 12121, Thailand. Vol. 21, No. 9, 931-951.

[32]. Hosmer, DW Jr. and Lemeshow, S. (2000). Applied Logistic Regression, second edition. New York: Wiley.

[33]. Ibrahim, I. (2001). Planning, development and education: vision for the future. First edition, Amman: Dar Zahran for publication and distribution.

[34]. Johnston, R., (1978). Multivariate Statistical Analysis in Geography.

[35]. Kline, R.B. (1998). Principles and practice of structural equation modeling. New York: The Guilford Press

[36]. Klocinski, J. (1999). Evaluation of success and failure factors and criteria in the Implementation of total quality management principles in administration at selected institutions of higher education.PhD thesis, University of Toledo, Toledo, $\mathrm{OH}$.

[37]. Morgan, C., \&Murgatroyd, S. (1997). Total quality management in the public sector. Buckingham, UK: Open University Press.

[38]. Nesbary, D.K. (2000). Survey research and the World Wide Web. Needham Heights, MA: Allyn and Bacon.

[39]. Nunnally, J., \&Burnstein, I.H. (1994).Pschychometric theory (3rd ed.). New York: McGraw Hill.

[40]. Oakland, J. S. 2003. Total Quality Management: text and cases, Oxford: ButterworthHeinemann.

[41]. Pandi.A.P., Rao, U.S. and Jeyathilagar, D. (2009). A Study of Integrated Total Quality Management, Practice in Technical Institutions Students Perspective. International Journal of Educational Administration, 1(1], pp. 17-30.

[42]. Petrides, L.A. (2003). Strategic planning and information use: The role of institutional leadership in the community college. On the Horizon, 11(4), 10-14.

[43]. Prajogo, D.I., \& Sohal, A.S. (2003). The multidimensionality of TQM practices in determining quality and innovation performance - an empirical examination. Technovation, 24, 443-453.

[44]. Riccardi, M.T., Venneberg, D., Makela C. (2009). Perceptions of community college presidents: total quality management performance measures at their colleges. Dissertation submitted to school of Education, Colorado State University Fort Collins, Colorado.

[45]. Saeed, H. (2001). Total quality management in higher education, a survey of a sample of professors and students of the faculties of Economics and Administration at the University of Baghdad and Mustansiriya. Unpublished MA Thesis, University of Baghdad, Baghdad, Iraq.

[46]. Saint, W. (2004) Higher Education in Ethiopia: The Vision and its Challenges, Boston College \& Council for the Development of Social Science Research in Africa

[47]. Samson, D., \& Terziovski, M. (1999).The relationship between total quality management practices and operational performance. Journal of Operations Management, 17, 393-409.

[48]. Sanyal, B. (1998). Strategies for higher education in Asia and the pacific in the past Cold-war era.11EP, contributions No.29.

[49]. Sims, S.J. and Sims, R.R. (1995).Total Quality Management in Higher Education: isit working? Why or why not? London: Praegar.

[50]. Singh V, Grover S. and Kumar. A. 2008. Evaluation of Quality in an Educational Institute: a quality function deployment approach. Educational research Review, 3(4], pp.162 168.

[51]. Smith.Armstrong, H, M. and Brown, S. (1999).Benchmarking andThreshold Standers in Higher Education. San Francisco: JosseyBass.

[52]. Suleiman, A. (1979). Mission and objectives of University education in a changing World.A series of silver jubilee, 3, 12-27.

[53]. Taylor, A.L., \& Karr, S. (1999). Strategic planning approaches used to respond to issues confronting research universities. Innovative Higher Education, 23(3), 221-234.

[54]. Voehl, F. (1994).Total Quality in Higher Education.Florida: St. Lucie Press.

[55]. Wahbe, N. (2003). Nature of education and quality. Beirut, Lebanon: NakhlehWehbeh Publisher.

[56]. Walton, M. (1985).The Deming management method. NY: Putnam publishing group.

[57]. Warner, D. and Palfreyman.D. (2000).Higher Education Management: The KeyElement. Suffolk: St Edmundsbury Press Ltd.

[58]. Zink, K. and Vob, W. (2000).The new EFQM excellence model and its impact on higher education institutions.In: Proceedings of the TQM for Higher Education InstitutionsConference: Higher Education Institutions and the Issue of Total Quality, 30-31 August, 1999 Verona. pp. 241-55. 
Table 4.1 Frequency Distribution of the respondents of each college

\begin{tabular}{|c|c|c|c|c|c|c|c|c|c|c|c|}
\hline & & \multicolumn{10}{|c|}{ Type of college } \\
\hline & & \multicolumn{4}{|c|}{ Private } & \multicolumn{4}{|c|}{ Governmental } & \multicolumn{2}{|l|}{ Total } \\
\hline & & Count & $\begin{array}{l}\text { Row } \\
\text { N \% }\end{array}$ & $\begin{array}{l}\text { Table } \\
\mathrm{N} \%\end{array}$ & $\begin{array}{l}\text { Column } \\
\mathrm{N} \%\end{array}$ & Count & $\begin{array}{l}\text { Row } \\
\text { N\% }\end{array}$ & $\begin{array}{l}\text { Table } \\
\text { N\% }\end{array}$ & $\begin{array}{l}\text { Column } \\
\mathrm{N} \%\end{array}$ & Count & $\begin{array}{l}\text { Table } \\
\text { N\% }\end{array}$ \\
\hline \multirow[t]{3}{*}{ Sex } & Female & 46 & 37.7 & 12.6 & 33.6 & 76 & 62.3 & 20.8 & 33.3 & 122 & 33.4 \\
\hline & Male & 91 & 37.4 & 24.9 & 66.4 & 152 & 62.6 & 41.6 & 66.7 & 243 & 66.6 \\
\hline & Total & 137 & 37.5 & 37.5 & 100.0 & 228 & 62.5 & 62.5 & 100.0 & 365 & 100.0 \\
\hline \multirow{6}{*}{$\begin{array}{l}\text { Age of } \\
\text { respondents }\end{array}$} & $<21$ & 50 & 41.3 & 13.7 & 36.5 & 71 & 58.7 & 19.5 & 31.1 & 121 & 33.2 \\
\hline & $21-30$ & 76 & 39.6 & 20.8 & 55.5 & 116 & 60.4 & 31.8 & 50.9 & 192 & 52.6 \\
\hline & $31-40$ & 7 & 21.9 & 1.9 & 5.1 & 25 & 78.1 & 6.8 & 11.0 & 32 & 8.8 \\
\hline & $41-50$ & 1 & 10.0 & 0.3 & 0.7 & 9 & 90.0 & 2.5 & 3.9 & 10 & 2.7 \\
\hline & $>50$ & 3 & 30.0 & 0.8 & 2.2 & 7 & 70.0 & 1.9 & 3.1 & 10 & 2.7 \\
\hline & Total & 137 & 37.5 & 37.5 & & 228 & 62.5 & 62.5 & 100.0 & 365 & 100.0 \\
\hline \multirow{4}{*}{$\begin{array}{l}\text { Year of stay } \\
\text { in the } \\
\text { college }\end{array}$} & Short & 50 & 36.5 & 13.7 & 36.5 & 87 & 63.5 & 23.8 & 38.2 & 137 & 37.5 \\
\hline & Medium & 44 & 43.6 & 12.1 & 32.1 & 57 & 56.4 & 15.6 & 25.0 & 101 & 27.7 \\
\hline & Long & 43 & 33.9 & 11.8 & 31.4 & 84 & 66.1 & 23.0 & 36.8 & 127 & 34.8 \\
\hline & Total & 137 & 37.5 & 37.5 & 100.0 & 228 & 62.5 & 62.5 & 100.0 & 365 & 100.0 \\
\hline \multirow{3}{*}{$\begin{array}{l}\text { Position of } \\
\text { the } \\
\text { respondents }\end{array}$} & Customer/Student & 129 & 38.7 & 35.3 & 94.2 & 204 & 61.3 & 55.9 & 89.5 & 333 & 91.2 \\
\hline & Employee & 8 & 25.0 & 2.2 & 5.8 & 24 & 75.0 & 6.6 & 10.5 & 32 & 8.8 \\
\hline & Total & 137 & 37.5 & 37.5 & 100.0 & 228 & 62.5 & 62.5 & 100.0 & 365 & 100.0 \\
\hline
\end{tabular}

Table 4.2 Frequency Distribution of the positions of respondents in each college

\begin{tabular}{|c|c|c|c|c|c|c|c|c|c|c|c|}
\hline \multicolumn{2}{|l|}{ Colleges } & \multicolumn{10}{|c|}{ Position of the respondents in the college } \\
\hline & & \multicolumn{4}{|c|}{ Customer/Student } & \multicolumn{4}{|c|}{ Employee } & \multirow[b]{2}{*}{ Count } & \multirow{2}{*}{$\begin{array}{l}\text { Total } \\
\text { Table } \mathrm{N} \\
\%\end{array}$} \\
\hline & & Count & $\begin{array}{l}\text { Row N } \\
\%\end{array}$ & $\begin{array}{l}\text { Table N } \\
\%\end{array}$ & $\begin{array}{l}\text { Column N } \\
\%\end{array}$ & Count & $\begin{array}{l}\text { Row N } \\
\%\end{array}$ & $\begin{array}{l}\text { Table } \\
\mathrm{N} \%\end{array}$ & $\begin{array}{l}\text { Column N } \\
\%\end{array}$ & & \\
\hline \multirow{12}{*}{$\begin{array}{l}\text { College ID } \\
\text { indicated }\end{array}$} & GC1 & 70 & $90.9 \%$ & $19.2 \%$ & $21.0 \%$ & 7 & $9.1 \%$ & $1.9 \%$ & $21.9 \%$ & 77 & $21.1 \%$ \\
\hline & GC2 & 27 & $87.1 \%$ & $7.4 \%$ & $8.1 \%$ & 4 & $12.9 \%$ & $1.1 \%$ & $12.5 \%$ & 31 & $8.5 \%$ \\
\hline & GC3 & 43 & $86.0 \%$ & $11.8 \%$ & $12.9 \%$ & 7 & $14.0 \%$ & $1.9 \%$ & $21.9 \%$ & 50 & $13.7 \%$ \\
\hline & GC4 & 61 & $92.4 \%$ & $16.7 \%$ & $18.3 \%$ & 5 & $7.6 \%$ & $1.4 \%$ & $15.6 \%$ & 66 & $18.1 \%$ \\
\hline & GC5 & 3 & $75.0 \%$ & $0.8 \%$ & $0.9 \%$ & 1 & $25.0 \%$ & $0.3 \%$ & $3.1 \%$ & 4 & $1.1 \%$ \\
\hline & Subtotal & 204 & $89.5 \%$ & $55.9 \%$ & $61.3 \%$ & 24 & $10.5 \%$ & $6.6 \%$ & $75.0 \%$ & 228 & $62.5 \%$ \\
\hline & PC1 & 34 & $89.5 \%$ & $9.3 \%$ & $10.2 \%$ & 4 & $10.5 \%$ & $1.1 \%$ & $12.5 \%$ & 38 & $10.4 \%$ \\
\hline & $\mathrm{PC} 2$ & 54 & $98.2 \%$ & $14.8 \%$ & $16.2 \%$ & 1 & $1.8 \%$ & $0.3 \%$ & $3.1 \%$ & 55 & $15.1 \%$ \\
\hline & PC3 & 12 & $92.3 \%$ & $3.3 \%$ & $3.6 \%$ & 1 & $7.7 \%$ & $0.3 \%$ & $3.1 \%$ & 13 & $3.6 \%$ \\
\hline & PC4 & 18 & $94.7 \%$ & $4.9 \%$ & $5.4 \%$ & 1 & $5.3 \%$ & $0.3 \%$ & $3.1 \%$ & 19 & $5.2 \%$ \\
\hline & PC5 & 11 & $91.7 \%$ & $3.0 \%$ & $3.3 \%$ & 1 & $8.3 \%$ & $0.3 \%$ & $3.1 \%$ & 12 & $3.3 \%$ \\
\hline & Subtotal & 129 & $94.2 \%$ & $35.3 \%$ & $38.7 \%$ & 8 & $5.8 \%$ & $2.2 \%$ & $25.0 \%$ & 137 & $37.5 \%$ \\
\hline
\end{tabular}


Assessment of the Effective total quality management on performance at selective colleges in Tigray..

\begin{tabular}{|l|l|l|l|l|l|l|l|l|l|l|l|}
\hline & Total & 333 & $91.2 \%$ & $91.2 \%$ & $100.0 \%$ & 32 & $8.8 \%$ & $8.8 \%$ & $100.0 \%$ & 365 & $100.0 \%$ \\
\hline
\end{tabular}

Table 4.3 Frequency Distribution of the respondents' opinion on Practice of TQM and Product and or/Service

Quality of their college

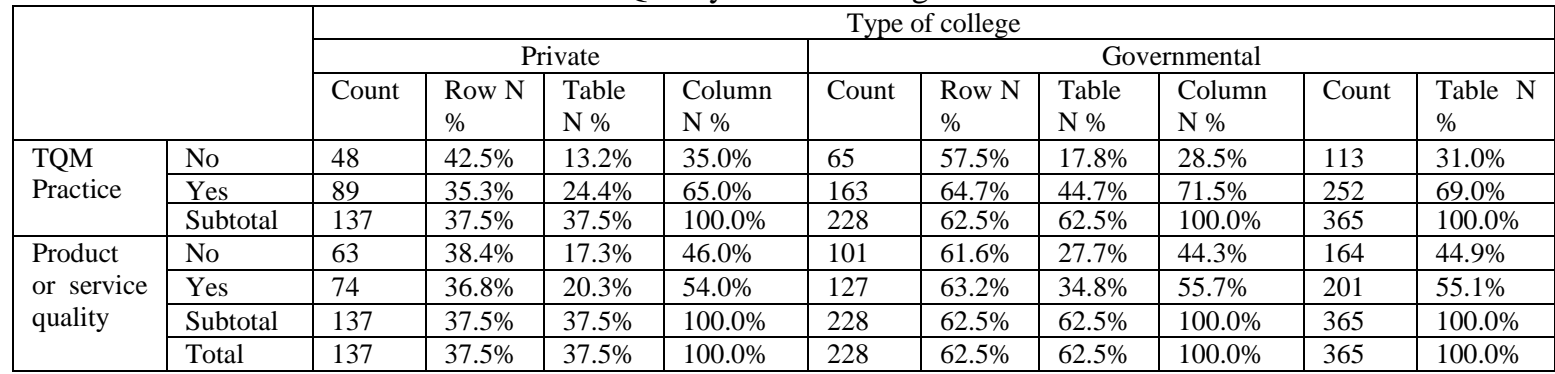

Table 4.4 The respondents' opinion on availability of CI, cooperation and QIC in their colleges.

\begin{tabular}{|c|c|c|c|c|c|c|c|c|c|c|c|}
\hline & \multicolumn{9}{|c|}{ Type of college } & \multirow[b]{2}{*}{ Total } \\
\hline & & \multicolumn{4}{|c|}{ Private } & \multicolumn{4}{|c|}{ Governmental } & \multirow[b]{2}{*}{ Count } & \\
\hline & & Count & $\begin{array}{l}\text { Row } \\
\mathrm{N} \% \\
\end{array}$ & $\begin{array}{l}\text { Column } \\
\mathrm{N} \% \\
\end{array}$ & $\begin{array}{l}\text { Table } \\
\mathrm{N} \%\end{array}$ & Count & $\begin{array}{l}\text { Row } \\
\mathrm{N} \% \\
\end{array}$ & $\begin{array}{l}\text { Column } \\
\mathrm{N} \%\end{array}$ & $\begin{array}{l}\text { Table } \\
\mathrm{N} \%\end{array}$ & & \begin{tabular}{l|l} 
Table \\
$\mathrm{N} \%$
\end{tabular} \\
\hline \multirow{2}{*}{$\begin{array}{l}\text { Continuous } \\
\text { improvement }\end{array}$} & No & 122 & $36.3 \%$ & $89.1 \%$ & $33.4 \%$ & 214 & $63.7 \%$ & $93.9 \%$ & $58.6 \%$ & 336 & $92.1 \%$ \\
\hline & Yes & 15 & $51.7 \%$ & $10.9 \%$ & $4.1 \%$ & 14 & $48.3 \%$ & $6.1 \%$ & $3.8 \%$ & 29 & $7.9 \%$ \\
\hline \multirow{2}{*}{$\begin{array}{l}\text { Internal /External } \\
\text { Cooperation }\end{array}$} & No & 83 & $40.9 \%$ & $60.6 \%$ & $22.7 \%$ & 120 & $59.1 \%$ & $52.6 \%$ & $32.9 \%$ & 203 & $55.6 \%$ \\
\hline & Yes & 54 & $33.3 \%$ & $39.4 \%$ & $14.8 \%$ & 108 & $66.7 \%$ & $47.4 \%$ & $29.6 \%$ & 162 & $44.4 \%$ \\
\hline \multirow{3}{*}{$\begin{array}{l}\text { Quality } \\
\text { improvement } \\
\text { Counsel }\end{array}$} & No & 44 & $38.6 \%$ & $32.1 \%$ & $12.1 \%$ & 70 & $61.4 \%$ & $30.7 \%$ & $19.2 \%$ & 114 & $31.2 \%$ \\
\hline & Yes & 93 & $37.1 \%$ & $67.9 \%$ & $25.5 \%$ & 158 & $62.9 \%$ & $69.3 \%$ & $43.3 \%$ & 251 & $68.8 \%$ \\
\hline & Total & 137 & $37.5 \%$ & $100.0 \%$ & $37.5 \%$ & 228 & $62.5 \%$ & $100.0 \%$ & $62.5 \%$ & 365 & $100.0 \%$ \\
\hline
\end{tabular}

Table 4.5 The respondents' opinion on kind of leadership and employee fulfillment in colleges.

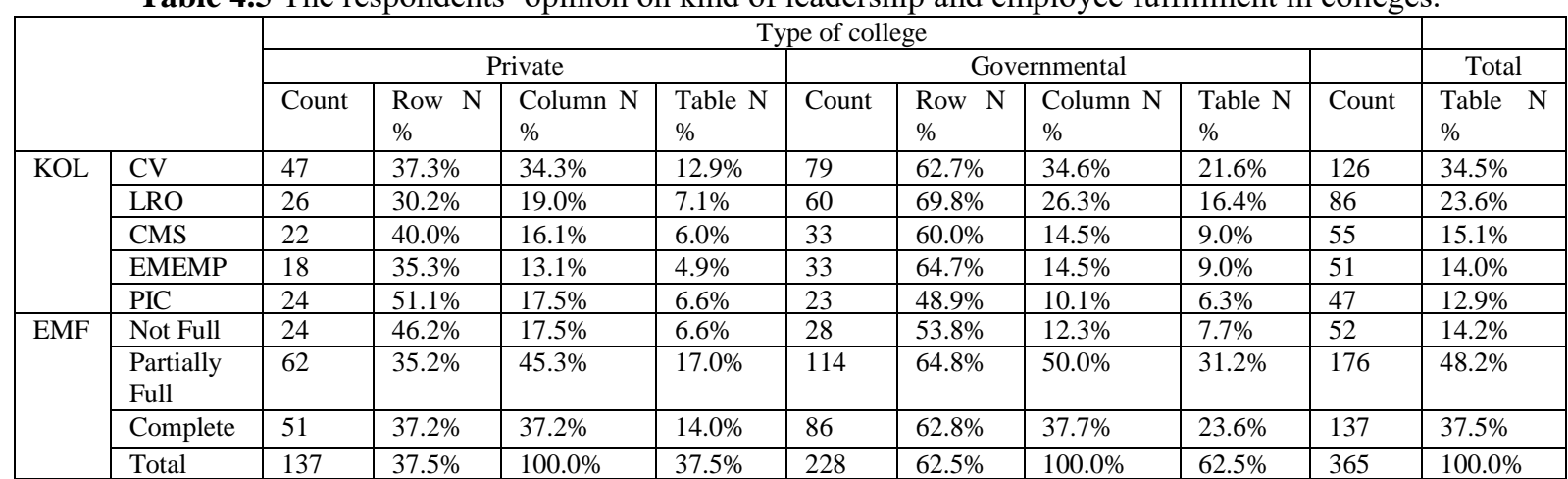

Table 4.6 Binary Logistic Regression for Practice on TQM

\begin{tabular}{|c|c|c|c|c|c|c|c|c|c|}
\hline \multicolumn{10}{|c|}{ Variables in the Equation } \\
\hline & & B & S.E. & Wald & df & Sig. & $\operatorname{Exp}(B)$ & \multicolumn{2}{|c|}{ 95\% C.I.for EXP(B) } \\
\hline & & & & & & & & Lower & Upper \\
\hline \multicolumn{2}{|r|}{ Constant } & -1.469 & 0.570 & 6.654 & 1 & 0.010 & 0.230 & & \\
\hline \multirow[t]{12}{*}{ Step $1^{a}$} & TypeC(1) & 0.924 & 0.352 & 6.890 & 1 & 0.009 & 2.520 & 1.264 & 5.024 \\
\hline & Period(1) & 1.150 & 0.335 & 11.797 & 1 & 0.001 & 3.158 & 1.638 & 6.087 \\
\hline & Period(2) & 0.942 & 0.546 & 2.976 & 1 & 0.084 & 2.566 & 0.880 & 7.485 \\
\hline & KOL(1) & 0.872 & 0.430 & 4.112 & 1 & 0.043 & 2.392 & 1.030 & 5.556 \\
\hline & KOL(2) & 1.707 & 0.499 & 11.680 & 1 & 0.001 & 5.510 & 2.071 & 14.662 \\
\hline & KOL(3) & 1.334 & 0.479 & 7.747 & 1 & 0.005 & 3.794 & 1.484 & 9.704 \\
\hline & KOL(4) & 0.931 & 0.403 & 5.345 & 1 & 0.021 & 2.538 & 1.152 & 5.590 \\
\hline & $\mathrm{CI}(1)$ & 1.156 & 0.561 & 4.242 & 1 & 0.039 & 3.176 & 1.057 & 9.538 \\
\hline & Cooperation(1) & 0.211 & 0.260 & 0.660 & 1 & 0.417 & 1.235 & 0.742 & 2.053 \\
\hline & $\mathrm{QIC}(1)$ & 0.375 & 0.287 & 1.705 & 1 & 0.192 & 1.455 & 0.829 & 2.556 \\
\hline & Employee(1) & 1.646 & 0.639 & 6.636 & 1 & 0.010 & 5.184 & 1.482 & 18.129 \\
\hline & Employee(2) & -1.029 & 0.266 & 14.963 & 1 & 0.000 & 0.358 & 0.212 & 0.602 \\
\hline
\end{tabular}

Table 4.7 Binary Logistic Regression for Product and /or Service Quality

\begin{tabular}{|l|l|l|l|l|l|l|l|l|}
\hline \multicolumn{2}{|c|}{ Variables in the Equation } \\
\hline & B & S.E. & Wald & df & Sig. & Exp(B) & \multicolumn{2}{|l|}{ 95\% C.I.for EXP(B) } \\
\cline { 2 - 8 } & & & & & & & Lower & Upper \\
\hline
\end{tabular}


Assessment of the Effective total quality management on performance at selective colleges in Tigray..

\begin{tabular}{|l|l|l|l|l|l|l|l|l|l|}
\hline \multicolumn{2}{|c|}{ Constant } & -1.385 & 0.620 & 4.993 & 1 & 0.025 & 0.250 & & \\
\hline Step 1 & TypeC(1) & 0.001 & 0.283 & 0.000 & 1 & 0.996 & 1.001 & 0.575 & 1.745 \\
\cline { 2 - 10 } & Period(1) & -0.266 & 0.282 & 0.894 & 1 & 0.344 & 0.766 & 0.441 & 1.331 \\
\cline { 2 - 10 } & Period(2) & 0.112 & 0.477 & 0.055 & 1 & 0.814 & 1.119 & 0.439 & 2.850 \\
\cline { 2 - 9 } & KOL(1) & 0.887 & 0.393 & 5.104 & 1 & 0.024 & 2.428 & 1.125 & 5.240 \\
\cline { 2 - 9 } & KOL(2) & 1.162 & 0.428 & 7.367 & 1 & 0.007 & 3.198 & 1.381 & 7.403 \\
\cline { 2 - 9 } & KOL(3) & 0.837 & 0.427 & 3.836 & 1 & 0.050 & 2.310 & 0.999 & 5.338 \\
\cline { 2 - 9 } & KOL(4) & 0.915 & 0.372 & 6.038 & 1 & 0.014 & 2.496 & 1.203 & 5.179 \\
\cline { 2 - 9 } & CI(1) & 0.876 & 0.415 & 4.453 & 1 & 0.035 & 2.400 & 1.064 & 5.413 \\
\cline { 2 - 9 } & Cooperation(1) & 0.112 & 0.222 & 0.256 & 1 & 0.613 & 1.119 & 0.724 & 1.730 \\
\cline { 2 - 9 } & QIC(1) & 0.044 & 0.238 & 0.034 & 1 & 0.854 & 1.045 & 0.656 & 1.665 \\
\cline { 2 - 9 } & Employee(1) & 0.723 & 0.351 & 4.230 & 1 & 0.040 & 2.060 & 1.035 & 4.402 \\
\cline { 2 - 8 } & Employee(2) & -0.127 & 0.238 & 0.287 & 1 & 0.592 & 0.881 & 0.553 & 1.403 \\
\hline
\end{tabular}

Table 4.8. Test of goodness and Model summary

\begin{tabular}{|c|c|c|c|c|c|c|c|}
\hline \multicolumn{8}{|c|}{ Omnibus Tests of Model Coefficients } \\
\hline & & \multicolumn{3}{|c|}{ TQM Practice } & \multicolumn{3}{|c|}{ Product/Service Quality } \\
\hline & & Chi-square & $\mathrm{df}$ & Sig. & Chi-square & $\mathrm{df}$ & Sig. \\
\hline \multirow{3}{*}{$\begin{array}{l}\text { Step } \\
1\end{array}$} & Step & 78.618 & 12 & 0.000 & 19.813 & 12 & 0.071 \\
\hline & Block & 78.618 & 12 & 0.000 & 19.813 & 12 & 0.071 \\
\hline & Model & 78.618 & 12 & 0.000 & 19.813 & 12 & 0.071 \\
\hline \multicolumn{8}{|c|}{ Model Summary } \\
\hline Step & & $\begin{array}{l}-2 \quad \log \\
\text { likelihood }\end{array}$ & $\begin{array}{l}\text { Cox \& Snell R } \\
\text { Square }\end{array}$ & $\begin{array}{l}\text { Nagelkerke } \quad \mathrm{R} \\
\text { Square }\end{array}$ & $\begin{array}{l}-2 \text { Log } \\
\text { likelihood }\end{array}$ & $\begin{array}{l}\text { Cox \& Snell } \\
\text { R Square }\end{array}$ & $\begin{array}{l}\text { Nagelkerke } \\
\text { R Square }\end{array}$ \\
\hline 1 & & $373.085^{\mathrm{a}}$ & 0.194 & 0.273 & $482.427^{\mathrm{a}}$ & 0.053 & 0.071 \\
\hline \multicolumn{8}{|c|}{ Hosmer and Lemeshow Test } \\
\hline Step & & Chi-square & df & Sig. & Chi-square & $\mathrm{df}$ & Sig. \\
\hline 1 & & 12.001 & 8 & 0.151 & 3.861 & 8 & 0.869 \\
\hline
\end{tabular}

Table 4.9 The Total Variance Explained by Five Constructs of TQM (Independent variables)

\begin{tabular}{|l|l|l|l|}
\hline \multicolumn{4}{|c|}{ Total Variance Explained(For Independent Factors) } \\
\cline { 2 - 4 } & Total & \% of Variance & Cumulative \% \\
\hline 1 & 3.657 & 18.284 & 18.284 \\
\hline 2 & 3.546 & 17.730 & 36.014 \\
\hline 3 & 2.654 & 13.271 & 49.285 \\
\hline 4 & 2.207 & 11.034 & 60.319 \\
\hline 5 & 2.015 & 10.074 & 70.393 \\
\hline \multicolumn{4}{|l|}{ Total Variance Explained(For Dependent Variables) } \\
\hline Component & Rotation Sums of Squared Loadings \\
\cline { 2 - 4 } & Total & \% of Variance & Cumulative \% \\
\hline 1 & 3.833 & 42.586 & 42.586 \\
\hline 2 & 3.083 & 34.256 & 76.842 \\
\hline Extraction Method: Principal Component Analysis. \\
\hline
\end{tabular}

Table 4.11 Multiple Linear Regression model for Satisfaction

\begin{tabular}{|c|c|c|c|c|c|c|}
\hline Predictors & Coefficients $(\beta)$ & SE & $\mathrm{t}$ & $p$-value & \multicolumn{2}{|c|}{$95 \% \mathrm{CI}$} \\
\hline & & & & & Lower & Upper \\
\hline Constant & 0.003 & 0.111 & 0.025 & 980 & -0.220 & 0.225 \\
\hline CType(Gov’tal) & -0.006 & 0.159 & -0.035 & 0.972 & -0.324 & 0.313 \\
\hline Leadership & 0.249 & 0.079 & 3.135 & 0.003 & 0.090 & 0.407 \\
\hline $\mathrm{CI}$ & 0.274 & 0.079 & 3.457 & 0.001 & 0.115 & 0.432 \\
\hline Employee & 0.681 & 0.078 & 8.694 & 0.000 & 0.525 & 0.838 \\
\hline Cooperation & 0.080 & 0.078 & 1.024 & 0.310 & -0.076 & 0.237 \\
\hline Customer Focus & 0.020 & 0.084 & 0.245 & 0.807 & -0.147 & 0.188 \\
\hline \multicolumn{7}{|c|}{ Model Summary } \\
\hline Model & $\begin{array}{c}\text { Correlation } \\
\text { Coefficient(r) }\end{array}$ & \multicolumn{2}{|c|}{$\begin{array}{c}\text { Coefficient of } \\
\text { Determination }\left(R^{2}\right)\end{array}$} & $\begin{array}{l}\text { Adjusted R- } \\
\text { Square }\end{array}$ & \multicolumn{2}{|c|}{$\begin{array}{c}\text { Standard Error of the } \\
\text { Estimates }\end{array}$} \\
\hline & 0.783 & \multicolumn{2}{|l|}{0.614} & 0.577 & \multicolumn{2}{|l|}{0.6504} \\
\hline \multicolumn{7}{|c|}{ ANC } \\
\hline Model & $\begin{array}{l}\text { Sum Squares } \\
\text { (SS) }\end{array}$ & $\overline{\mathrm{DF}}$ & $\begin{array}{l}\text { Mean } \\
\text { Square(MS) }\end{array}$ & $\mathrm{F}$ & \multicolumn{2}{|c|}{ P-Value(Sig.) } \\
\hline Regression & 42.348 & 6 & 7.058 & 16.684 & \multicolumn{2}{|l|}{0.000} \\
\hline Residual & 26.652 & 63 & 0.423 & & \\
\hline Total & 69.000 & 69 & & & & \\
\hline
\end{tabular}

Table 4.12 Results of Multiple Linear Regression model for Products \& service Quality

\begin{tabular}{|c|c|c|c|c|c}
\hline Predictors & Coefficients $(\beta)$ & SE & $\mathrm{t}$ & $\mathrm{p}$-value & $95 \% \mathrm{CI}$ \\
\hline
\end{tabular} 
Assessment of the Effective total quality management on performance at selective colleges in Tigray..

\begin{tabular}{|c|c|c|c|c|c|c|}
\hline & & & & & Lower & Upper \\
\hline Constant & 0.022 & 0.121 & 0.184 & 0.855 & -0.220 & 0.265 \\
\hline CType $(\mathrm{G})$ & -0.045 & 0.175 & -0.255 & 0.799 & -0.395 & 0.305 \\
\hline Leadership & 0.413 & 0.105 & 3.927 & 0.000 & 0.203 & 0.623 \\
\hline $\mathrm{CI}$ & 0.285 & 0.086 & 3.323 & 0.001 & 0.114 & 0.456 \\
\hline Employee & 0.663 & 0.085 & 7.818 & 0.000 & 0.494 & 0.833 \\
\hline Cooperation & 0.226 & 0.105 & 2.152 & 0.035 & 0.016 & 0.436 \\
\hline Customerfocus & -0.095 & 0.085 & -1.123 & 0.266 & -0.264 & 0.074 \\
\hline \multicolumn{7}{|c|}{ Model Summary } \\
\hline Model & $\begin{array}{c}\text { Correlation } \\
\text { Coefficient(r) }\end{array}$ & \multicolumn{2}{|c|}{ Coefficient of Determination $\left(R^{2}\right)$} & $\begin{array}{c}\text { Adjusted R- } \\
\text { Square }\end{array}$ & \multicolumn{2}{|c|}{$\begin{array}{c}\text { Standard Error of the } \\
\text { Estimates }\end{array}$} \\
\hline & 0.741 & \multicolumn{2}{|l|}{0.549} & 0.506 & \multicolumn{2}{|c|}{0.7030} \\
\hline \multicolumn{7}{|c|}{ ANOVA } \\
\hline Model & $\begin{array}{l}\text { Sum Squares } \\
\text { (SS) }\end{array}$ & DF & Mean Square(MS) & $\mathrm{F}$ & \multicolumn{2}{|c|}{ P-Value(Sig.) } \\
\hline Regression & 37.869 & 6 & 6.312 & 12.773 & \multicolumn{2}{|l|}{0.000} \\
\hline Residual & 31.131 & 63 & 0.494 & & \\
\hline Total & 69.000 & 69 & & & \\
\hline
\end{tabular}

Table C.1 descriptive statistics original variables

\begin{tabular}{|c|c|c|c|}
\hline \multicolumn{4}{|l|}{ Descriptive Statistics } \\
\hline & Mean & Std. & $\mathrm{N}$ \\
\hline Senior administrators share similar beliefs about the future direction of this college & 3.27 & 2.119 & 70 \\
\hline $\begin{array}{l}\text { Activities and investments that have long-term benefits receive little support from senior } \\
\text { administrators }\end{array}$ & 3.40 & 1.244 & 70 \\
\hline $\begin{array}{l}\text { Employees have the opportunity to share in and are encouraged to help the college implement } \\
\text { change }\end{array}$ & 3.36 & 1.240 & 70 \\
\hline Administrators and supervisors rarely allow employees to take necessary actions on their own & 3.84 & 1.293 & 70 \\
\hline Senior administrators anticipate change and make plans to accommodate & 3.24 & 1.122 & 70 \\
\hline $\begin{array}{l}\text { This college encourages continual study and improvement of all its products, services, and } \\
\text { processes }\end{array}$ & 3.74 & 2.005 & 70 \\
\hline $\begin{array}{l}\text { Employees usually don't get an opportunity to suggest changes or modifications to existing } \\
\text { processes }\end{array}$ & 3.40 & 1.279 & 70 \\
\hline Many of our services have been improved in the recent past & 3.16 & 1.337 & 70 \\
\hline $\begin{array}{l}\text { This college has received recent compliments and recognition for improving its services and } \\
\text { processes }\end{array}$ & 3.19 & 1.322 & 70 \\
\hline $\begin{array}{l}\text { My work duties and responsibilities contribute little to satisfying my need to create quality } \\
\text { services }\end{array}$ & 3.36 & 1.694 & 70 \\
\hline Employees in this college are dedicated to their jobs & 3.83 & 1.494 & 70 \\
\hline $\begin{array}{l}\text { Administrators and supervisors create a work environment that encourages employees to } \\
\text { perform to the best of their abilities }\end{array}$ & 3.83 & 1.606 & 70 \\
\hline $\begin{array}{l}\text { Administrators, supervisors, and employees from different departments work independently to } \\
\text { achieve their own department's goals }\end{array}$ & 3.76 & 1.959 & 70 \\
\hline In this college, teamwork is common & 3.00 & 1.445 & 70 \\
\hline In this college, everyone participates in improving our products, services, and processes & 3.16 & 1.538 & 70 \\
\hline Senior administrators look at the "whole picture" when they make decisions & 3.31 & 1.602 & 70 \\
\hline $\begin{array}{l}\text { Senior administrators insist on accuracy and reliability of all information and communications } \\
\text { within the college }\end{array}$ & 3.27 & 1.541 & 70 \\
\hline Our processes and activities are centered on satisfying our customers & 4.14 & 1.875 & 70 \\
\hline Administrators and supervisors encourage activities that improve customer satisfaction & 3.21 & 1.710 & 70 \\
\hline Senior administrators behave in ways that lessen the importance of our customers & 3.04 & 1.637 & 70 \\
\hline Our services usually have some kind of mistakes, defects, or errors. & 3.70 & 1.747 & 70 \\
\hline
\end{tabular}

Table C.2 Factor analysis result for rotated component Matrix for independent variables Rotated Component Matrix ${ }^{\mathrm{a}}$

\begin{tabular}{|c|c|c|c|c|c|c|}
\hline \multicolumn{6}{|l|}{ Rotated Component Matrix ${ }^{a}$} & \\
\hline & \multicolumn{5}{|c|}{ Component } & \\
\hline & 1 & 2 & 3 & 4 & 5 & \\
\hline $\begin{array}{l}\text { Senior administrators share similar beliefs about the future direction of } \\
\text { this college }\end{array}$ & .174 & -.642 & .435 & -.020 & -.027 & \multirow{5}{*}{ 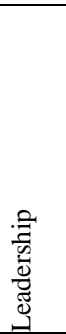 } \\
\hline $\begin{array}{l}\text { Activities and investments that have long-term benefits receive little } \\
\text { support from senior administrators }\end{array}$ & .195 & .834 & -.136 & -.025 & -.025 & \\
\hline $\begin{array}{l}\text { Employees have the opportunity to share in and are encouraged to help } \\
\text { the college implement change }\end{array}$ & -.087 & .854 & -.117 & .022 & .022 & \\
\hline $\begin{array}{l}\text { Administrators and supervisors rarely allow employees to take } \\
\text { necessary actions on their own }\end{array}$ & -.039 & .820 & -.249 & -.006 & -.005 & \\
\hline $\begin{array}{l}\text { Senior administrators anticipate change and make plans to } \\
\text { accommodate it }\end{array}$ & .044 & .866 & -.059 & -.040 & .082 & \\
\hline $\begin{array}{l}\text { This college encourages continual study and improvement of all its } \\
\text { products, services, and processes }\end{array}$ & -.061 & -.037 & .008 & -.735 & .149 & 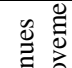 \\
\hline $\begin{array}{l}\text { Employees usually don't get an opportunity to suggest changes or } \\
\text { modifications to existing processes }\end{array}$ & -.135 & -.149 & -.107 & .755 & .182 & 远 范 \\
\hline
\end{tabular}




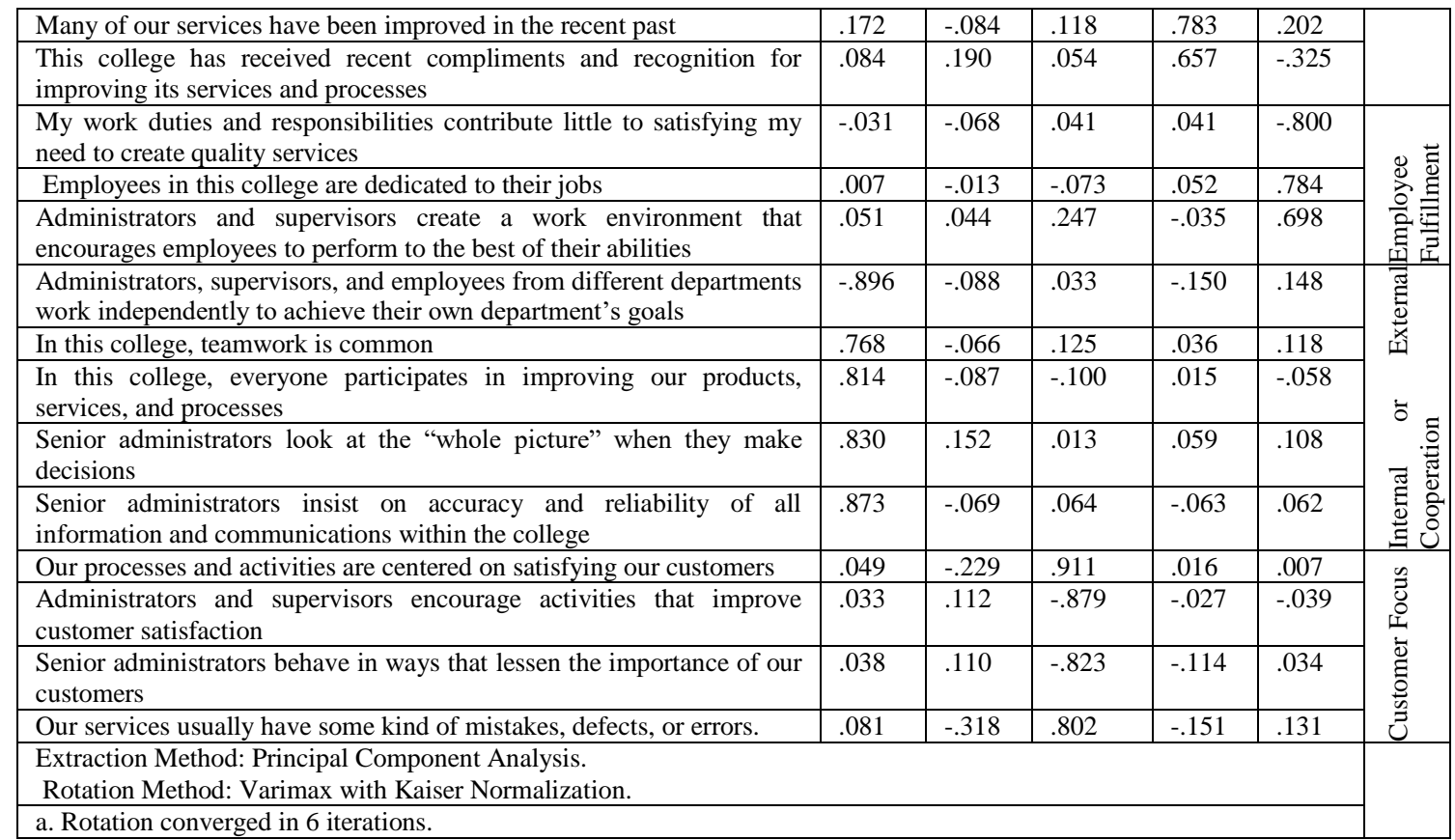

Table C.3 Factor analysis result for rotated component Matrix for dependent variables

\begin{tabular}{|c|c|c|c|}
\hline \multicolumn{3}{|l|}{ Rotated Component Matrix ${ }^{\mathrm{a}}$} & \multirow{3}{*}{ Constructs of TQM Variables } \\
\hline & \multicolumn{2}{|c|}{ Component } & \\
\hline & 1 & 2 & \\
\hline Our services usually have some kind of mistakes, defects, or errors. & -.245 & -.880 & \multirow{4}{*}{ 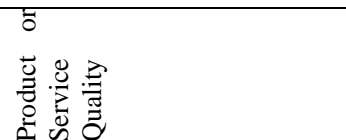 } \\
\hline Our services have all necessary parts, features, or elements & .172 & .826 & \\
\hline Our services meet customers' requirements & .549 & .676 & \\
\hline This college doesn't develop new ideas or methods in its services & .447 & .765 & \\
\hline Satisfaction results show improvement over time & -.910 & -.206 & \multirow{5}{*}{ 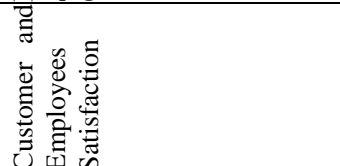 } \\
\hline This college lacks a process to provide satisfactory responses to inquiries & .826 & .219 & \\
\hline This college has processes in place to listen to and resolve complaints & .666 & .487 & \\
\hline This college has very low employee turnover & .795 & .408 & \\
\hline Employees file very few complaints against administration in this college & .811 & .303 & \\
\hline
\end{tabular}

